\title{
The Impact of Obesity, Adipose Tissue, and Tumor Microenvironment on Macrophage Polarization and Metastasis
}

\author{
Ola Habanjar ${ }^{1}$, Mona Diab-Assaf ${ }^{2}$, Florence Caldefie-Chezet ${ }^{1}$ and Laetitia Delort ${ }^{1, *(D)}$ \\ 1 Université Clermont-Auvergne, INRAE, UNH, ECREIN, f-63000 Clermont-Ferrand, France; \\ ola.habanjar@etu.uca.fr (O.H.); florence.caldefie-chezet@uca.fr (F.C.-C.) \\ 2 Equipe Tumorigénèse Pharmacologie moléculaire et anticancéreuse, Faculté des Sciences II, \\ Université libanaise Fanar, Beyrouth 1500, Liban; mdiabassaf@ul.edu.lb \\ * Correspondence: laetitia.delort@uca.fr
}

check for updates

Citation: Habanjar, O.; Diab-Assaf, M.; Caldefie-Chezet, F.; Delort, L. The Impact of Obesity, Adipose Tissue, and Tumor Microenvironment on Macrophage Polarization and Metastasis. Biology 2022, 11, 339 https://doi.org/10.3390/ biology11020339

Academic Editor: Claudio Luparello

Received: 29 November 2021

Accepted: 15 February 2022

Published: 21 February 2022

Publisher's Note: MDPI stays neutral with regard to jurisdictional claims in published maps and institutional affiliations.

Copyright: (C) 2022 by the authors. Licensee MDPI, Basel, Switzerland. This article is an open access article distributed under the terms and conditions of the Creative Commons Attribution (CC BY) license (https:// creativecommons.org/licenses/by/ $4.0 /)$.
Simple Summary: The inflammatory adipose microenvironment in obesity plays a crucial role in cancer development and metastases. By focusing on adipocytes and macrophages, as well as the extracellular matrix, the cellular and molecular mechanisms that link inflammation, obesity, and cancer will be addressed by this review. After describing the tumor microenvironment and extracellular matrix, the influence of M1, M2, and tumor-associated macrophages will be explored through their origin, classification, polarization, and regulatory networks, including their potential role in angiogenesis, invasion, metastasis, and immunosuppression, with a specific focus on the roles of adipocytes in this process.

\begin{abstract}
Tumor metastasis is a major cause of death in cancer patients. It involves not only the intrinsic alterations within tumor cells, but also crosstalk between these cells and components of the tumor microenvironment (TME). Tumorigenesis is a complex and dynamic process, involving the following three main stages: initiation, progression, and metastasis. The transition between these stages depends on the changes within the extracellular matrix (ECM), in which tumor and stromal cells reside. This matrix, under the effect of growth factors, cytokines, and adipokines, can be morphologically altered, degraded, or reorganized. Many cancers evolve to form an immunosuppressive TME locally and create a pre-metastatic niche in other tissue sites. TME and pre-metastatic niches include myofibroblasts, immuno-inflammatory cells (macrophages), adipocytes, blood, and lymphatic vascular networks. Several studies have highlighted the adipocyte-macrophage interaction as a key driver of cancer progression and dissemination. The following two main classes of macrophages are distinguished: M1 (pro-inflammatory/anti-tumor) and M2 (anti-inflammatory/pro-tumor). These cells exhibit distinct microenvironment-dependent phenotypes that can promote or inhibit metastasis. On the other hand, obesity in cancer patients has been linked to a poor prognosis. In this regard, tumor-associated adipocytes modulate TME through the secretion of inflammatory mediators, which modulate and recruit tumor-associated macrophages (TAM). Hereby, this review describes the cellular and molecular mechanisms that link inflammation, obesity, and cancer. It provides a comprehensive overview of adipocytes and macrophages in the ECM as they control cancer initiation, progression, and invasion. In addition, it addresses the mechanisms of tumor anchoring and recruitment for M1, M2, and TAM macrophages, specifically highlighting their origin, classification, polarization, and regulatory networks, as well as their roles in the regulation of angiogenesis, invasion, metastasis, and immunosuppression, specifically highlighting the role of adipocytes in this process.
\end{abstract}

Keywords: extracellular matrix; tumor microenvironment; cancer-associated fibroblasts; metastasis ; immune-inflammatory cells; cancer-associated adipocytes; tumor-associated macrophages; macrophage polarization; angiogenesis; hypoxia 


\section{Introduction}

Cancer is typically associated with neo-angiogenesis, tumor-enhanced inflammation, and the uncontrolled growth of abnormal cells. Ultimately, malignant tumors invade normal tissue and spread throughout the body [1-3]. The extent of a tumor invasion is a key index of cancer severity. Highly invasive tumor cells gain access to blood vessels by leaving the primary tumor site and invading the surrounding tissues, reaching the blood and lymphatic vessels where they disseminate to remote organs [4-7]. The metastasis of these cancers accounts for approximately $90 \%$ of cancer-related deaths $[8,9]$. Historically, the search for metastasis began in 1889 by surgeon Stephen Paget, who hypothesized the concept of "seed and soil." This concept describes the dependence of cancer metastasis on tumor cells (seeds) and its complex interactions with the tumor microenvironment (TME) (soil) [10-12]. In fact, a non-neoplastic microenvironment can prevent tumor invasion and metastasis. The TME guides tumor scaffolds with new cell interactions to form a pre-metastatic niche (PMN). Generally, the PMN consists of (i) cellular components such as myofibroblasts, fibroblasts, adipocytes, and immune-inflammatory cells, and (ii) noncellular components of tumor niches such as extracellular matrix (ECM) including the blood and lymphatic networks [13].

The stroma is generally rich in active biomolecules such as growth factors (GFs) and cytokines. However, TME cells can regulate the behavior of tumor cells to strengthen or suppress the tumor [14-16]. Among these cells are macrophages, which make up to $50 \%$ of the mass of most tumors and produce an inflammatory microenvironment [17-19]. Inflammatory interventions in tumor metastases were first described by Virchow in 1867 [20]. Since then, many studies have identified the pathways and types of cell-cell and cell-matrix interactions. Macrophages are the most common inflammatory cells recruited towards the tumor site. They are present at all stages of tumor progression [21]. Leek and Harris described macrophages as the "Swiss Army knife" of the immune system [22], as they are involved in the regulation of tissue homeostasis, the inflammatory response to pathogens, and wound healing $[23,24]$. These cells show high phenotypic heterogeneity (different subpopulations) depending on the microenvironment $[25,26]$. It is possible to distinguish phenotypic M1 (inflammatory), M2 (neoplastic), and tumor-associated macrophages (TAMs). In primary tumors, macrophages can stimulate angiogenesis and improve tumor cell motility and infiltration. Then, during metastasis, they initiate the pre-metastatic site, promoting extravasation, survival, and the sustained growth of tumor cells. Macrophage polarization towards a tumor-promoting phenotype is due not only to the disruption of tissue homeostasis, but also to the interaction between malignant and stromal cells in TME [27]. Tumor initiation, progression, and metastasis are affected by dynamic changes in macrophage phenotypes. There is increasing evidence that defined subpopulations of macrophages are involved in these tumor-promoting activities. Metastases include hypoxia, angiogenesis (formation of a complete vasculature), and even overweight and obesity, as studies have shown a positive link between BMI and postmenopausal breast cancer risk [28]. Obesity increases the risk of death in both premenopausal and postmenopausal patients with breast cancer, but the effects of obesity on the risk of breast cancer in premenopausal (lower risk of ER-positive breast cancer) and postmenopausal (markedly higher risk of ER-positive breast cancer) women differ based on estrogen receptor (ER) status [29,30].

Possible interactions between the metabolism and the immune system in obese patients are currently a new area of research. Chronic low-grade inflammation is closely associated with obesity, which is closely associated with metastasis [31]. More specifically, obesityrelated fatty inflammation results from a pro-inflammatory dialogue between adipocytes and immune cells. Adipocytes in obese people are thought to be immunocompetent cells that play a direct immunological role in antigen presentation, $\mathrm{T}$ cell polarization (activated Th1), adipose tissue macrophage (ATM) recruitment, and M1 polarization [32-34]. Therefore, obesity/overweight (adipocytes), inflammation (macrophages), and tumors (transformed cells) form an important triangle that is proven to regulate TME [35-37]. 


\section{Tumor Microenvironment}

An ECM is a microenvironment with complex biomechanical and physico-chemical properties. This structure provides a platform for cell growth and tissue homeostasis in all organs [38-41]. Histologically, it is composed of the following two major parts: (i) the structural interstitial matrix surrounding the cells (collagen I and fibronectin FN) and (ii) the basement membrane (collagen IV, VIII, X, and laminins) [42-46]. Thanks to the masking of receptors by collagen, there are various proteins (collagen, FN), polysaccharides, GF-rich local deposits, and inactive bioactive molecules (metabolic precursors) [47-53]. Collagen (fibrotic and non-fibrotic) is the most abundant structural protein in human tissue, accounting for about $30 \%$ of the total protein content of the body [43,46,54-56]. It regulates adhesion, cell migration [56], and tensile strength to maintain homeostasis [57]. Basically, fibroblasts secrete interstitial collagen, FN, and metalloproteinases (MMPs) that degrade the ECM and most of the GFs that promote differentiation, growth, and cell migration [58-60]. FN binds these cells to the ECM [46], and thus forms a fibrous network [61]. It is involved in the organization of interstitial ECM through interaction with type I collagen [61-65] and in developing cell migration and tumor metastasis [66]. When cancer develops, various disorders appear in this matrix, exacerbating tumor progression. In general, this small disruption of orientation affects homeostasis and promotes malignant growth $[67,68]$, but the proper composition is sufficient to contain it $[69,70]$. Tumor cells cooperate with inflammatory cells to form PMNs that are beneficial for cancer progression [71]. The field of study has evolved over the years, explaining the role of primary tumors in altering the microenvironment to produce growth-favorable PMNs [12,72-74]. This PMN, in turn, promotes tumor growth under the effects of increased inflammation, vascular permeability, immunosuppression, and tissue rigidity [75-77]. As cancer grows rapidly, various dynamic interactions occur between these microenvironments, cancer cells, and resident cells [78-80]. It is important to note that the cooperation of transformed tumor cells and macrophages results in delayed cell-microenvironment interaction, cell proliferation, differentiation, and apoptosis [50,81,82]. Macrophages and tumor cells secrete various cytokines, chemokines, hormones, MMPs, Lysyl Oxidases (LOX: enzymes secreted by primary tumor cells for linear cross-linking of collagen) and GFs, which are initially interstitial. Such interaction activates fibroblasts and induces cancer-associated fibroblasts (CAFs) [40,83]. After activation, CAFs increase the regulation of FN, collagens I, III and IV, elastin, GFs (such as VEGF, which promotes vascular permeability, angiogenesis, and metastasis), and immunosuppressive cytokines (such as interleukin (IL)-22) [14-16,79,84-90]. This neosynthesized collagen deposition will be reoriented and cross-correlated primarily by LOX to form more rigid and large-aligned fibrils [70,91-93]. As a result, the linearization of collagen fibers, located along the edge, facilitates the invasion and tumor metastasis of neoplastic cells [94,95]. The alteration of the homeostatic balance is likely to create a "reactive" stroma that promotes a successive transition of transformed cells to invasive cancer, either by excessive production of GFs or through reciprocal interactions between stromal and tumor cells [96].

On the other hand, the adipose matrix influences TME. Generally, adipose tissue is complex and dynamic. It is composed mostly of white adipose tissue (WAT) containing adipose stem cells (ASC), immune cells (macrophages, lymphocytes), and endothelial cells [97]. It can create an adipose microenvironment rich in adipokines, estrogens, GFs, and proliferating hormones that surround the tumor [98,99]. Adipocytes, which can differentiate into numerous cell types, may function as endocrine and inflammatory cells. They contain a powerful energy depot (fatty acid) and, conversely, can secrete metabolic substrates, lipid agonists (loose fatty acid), pro-inflammatory molecules, numerous hormones, adipokines, GFs, and cytokines. Such activities set off both the persistent low-grade inflammation in adipose tissue related to weight problems and most cancer proliferation, migration, and remedy resistance [32-34,98,100-103]. Actually, the above-average proportion of adipose tissue in body weight (overweight or obesity) may be associated with an imbalance of many cells and hormonal metabolic pathways that increase the risk of most cancers [104] through reciprocal feedback between adipocytes and tumor cells [35,98,105-107]. Adipose cells se- 
crete approximately 50 exclusive cytokines, chemokines, and hormonal elements including IL-6, IL-8, IL-1 $\beta$, tumor necrosis factor (TNF)- $\alpha$, VEGF, CCL2, CCL5, and MMP9, which can also make a contribution to obesity and TME. Reciprocally, most cancer cells in this adipose matrix secrete diverse cytokines, which expand the formation of its PMN [37,108-110]. Elucidating the interaction between cancer-associated adipocytes (CAAs) in the TME and that between the TME and the adipose microenvironment (in obese or overweight individuals) during tumor invasion and progression is the focus of much investigation [111].

\section{Degradation of ECM and Metastases}

Biologically, tumor cells, CAFs, macrophages (TAM and M2), and CAAs are involved in the degradation of the ECM by MMP secretion [37,108-110,112-115]. MMPs are proteolytic enzymes that destroy the ECM surrounding the tumor, allowing tumor cells to escape the primary tumor and invade the surrounding tissue, thus enhancing metastases $[84,113,116,117]$. MMPs are normally secreted as zymogens (inactive) and activated in the extracellular space [118]. MMP's involvement in the ECM collagen degradation releases adhesion sites and targets receptors for activation of GF [59,119-122]. It also provides exposure of matrix signaling components [81,123]. Changes in biochemical composition and degradation of the basement membrane lead to changes in intracellular signaling and tumor spread [124,125]. These interactions generate positive counter-regulations that restimulate tumor growth and survival $[14,15,89]$. It can, therefore, be hypothesized that CAF is a major effector that contributes to the metastatic pro-inflammatory state [84,126], ECM remodeling, angiogenesis [127-131], perturbation of tissue homeostasis, ECM stiffness, and the stimulation of malignant progression by enhancing GF signaling $[15,70,132,133]$. Because the inhibition of MMPs may limit metastases, the role of MMPs in tumor invasion has attracted the attention of researchers in cancer treatment [134-137]. Metastasis is one of the main hallmarks of most malignant solid tumors, and research has already revealed several hypotheses that may explain the stimuli of metastasis phenomena. There are physical and natural barriers at the boundary between the epithelial cells and the matrix. In the case of cancer, these barriers interfere with the invasion of cancer cells and their attachment to the ECM. Such barriers may be related to the myoepithelial cell layer $[138,139]$. Tumor cell progression usually begins with a transformation of these barriers that can be disrupted (by MMPs) and/or altered (by invadopods, which are actin-rich, convex subcellular structures) for tumor cell migration. Metastases are further induced by ASCs, which can differentiate into other types of cancer-associated cells. Cancer-associated adipocytes (CAA) also secrete various cytokines, chemokines, hormonal factors, and MMPs (MMP-9) that enhance TME interactions and promote matrix degradation and metastasis [37,108-110,140-144].

The disappearance of these barriers is then dependent on several stimuli [138,139,145-151]. For example, mechanical stress induces a mechanical force that is managed by the rapid accumulation of cancer cells on the barrier layer. Cracks in the basement membrane are managed by cooperating with organisms that invade cancer cells. Invadopods, which initially initiate a convex branch, then expand to extend the cellular membrane and allow cancer cells to pass through the primary site to the stroma, thus promoting invasive anchoring. These invaders disrupt nearby healthy tissues because laminin and collagen IV are removed rather than completely broken down.

Once this barrier is impaired, tumor migration begins. The cancerous cells have the ability to cross the basement membrane from the primary sites, where they originate, to distant target sites via lymphatic vessels and/or blood circulation [4-7]. The epithelialmesenchymal transition (EMT) of differentiated epithelial cells is then characterized by the loss of epithelial cell properties and the acquisition of a new migratory mesenchymal phenotype [152]. In fact, cancer cells subjected to EMT (elongated form) can then migrate $[153,154]$. Since TME is an obligatory inducer of cancer growth $[76,155]$, the obligatory stages of tumor metastasis, known as the metastatic flow, are generally as follows: (a) Invasion of primary sites, (b) Invasion into the vascular system, (c) Survival within the circulation, (d) Extravascular extravasation and adaptation and growth in the metastatic 
niche [156-158]. Adipocytes, immune cells, and mediators of the inflammatory response may directly contribute to tumor growth and metastasis [159-163] (Figure 1). CAAs and several M2 and TAM macrophages secrete different soluble factors, such as IL-6, IL-8, IL-1 $\beta$, TNF- $\alpha$, and TGF- $\beta$ that participate in EMT to promote invasion [144,164-167]. In brief, the adipose matrix promotes interactions between adipocytes, vascular stromal cells, cancer cells, and macrophages during metastasis [168].

a)

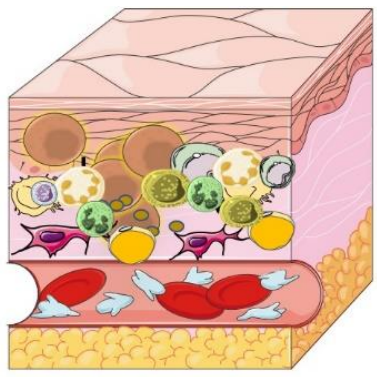

b)

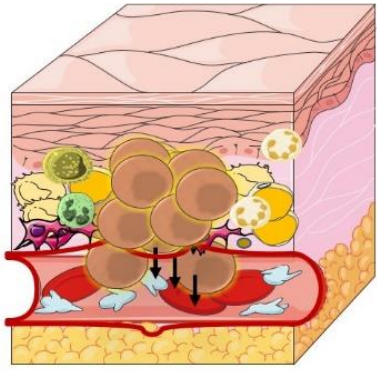

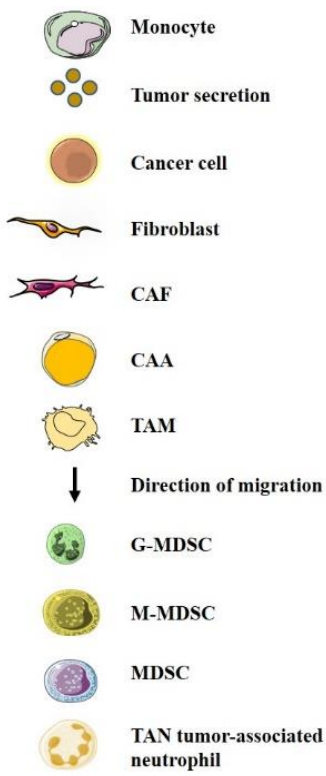
neutrophil d)

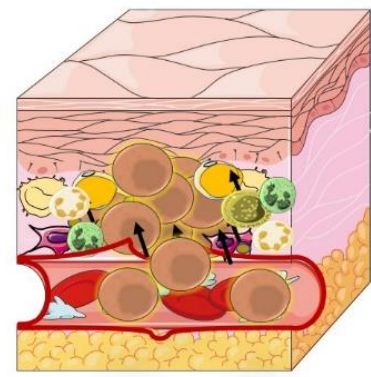

c)

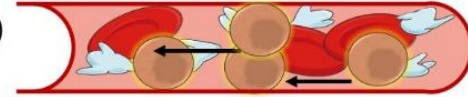

Figure 1. Different stages of cancer metastasis: (a) Invasion of primary sites, (b) Invasion into the vascular system, (c) Survival within the circulation, (d) Extravascular extravasation, adaptation, and growth in the metastatic niches.

\section{Tumor-Immune Interaction}

Phagocyte stimulation, a key step in immunity, was predicted by the Nobel Prizewinning Elie Metchnikoff in 1908 [169]. Macrophages are the first line of defense against infection [170,171], as they resolve acute inflammation [172], remove cell and apoptosis debris [173], regulate tissue stress and metabolic responses to apoptosis, and they intervene with the TME [174-176]. The first discovery of the presence of immune cells in human tumors was made by Virchow in 1863 [20]. This has led immunologists to investigate macrophages as immunophagocytic cells and effectors in most malignancies $[177,178]$. The density of macrophages in tumors increases with tumor progression [179-181]. Macrophages are not usually present in non-tumor tissues [182,183]. These cells are derived from the differentiation of the mononuclear phagocyte lineage. Peripheral blood monocytes eventually leave the blood circulation and are mobilized from the local circulation to the tumor where they differentiate into TAM $[22,159,184,185]$. TAMs and CAAs are important orchestrators for associating inflammation with cancer progression. Their differentiation is stimulated by chemotactic factors secreted by cancer cells [186-188] to promote tumor progression such as proliferation induction, ECM remodeling, angiogenesis, and adaptive immune evasion [189-191], either by the release of EGF [192], or by the degradation of ECM proteins (MMP2 and MMP9) [37,108-110,140-144,193-195]. Next, the high cytokine and chemokine levels released by monocytes, macrophages, tumor cells, fibroblasts, endothelial cells, and TAMs are key mediators that attract TAMs and monocytes to the tumor site [196-198]. Not all malignant tumors have constant high chemokine levels [199]. This pro-tumor microenvironment is a good response, primarily to promote metastasis. It reduces anti-cancer proteins and cytokines [200-204]. Second, it plays an important role in the development, progression, and infiltration of cancer to progress fastest. This can 
be summarized in the following three steps: removal, balance, and escape from immune surveillance $[27,179,205-208]$.

\section{Macrophage Polarization}

Circulating immature monocytes and bone marrow precursors released from the bone marrow differentiate into M1 or M2 macrophages [209-215]. Macrophages are a highly heterogenous population of cells that undergo extensive changes in their intracellular metabolism in response to environmental and inflammatory stimuli. M1/M2 classification has also been used to define macrophage polarization states, which are associated with different characteristics and functions. They can be M2-like as immunosuppressive or M1like as immune-stimulating (initiation of the inflammatory response) [216-219]. Thus, the M1/M2 cells do not simply describe activated or inactivated macrophages, but cells expressing distinct metabolic programs. They are, in fact, two functionally different macrophages produced by in vitro differentiation of monocytes [220]. That is, they can exhibit cytotoxic activity as the first line of defense against tumor formation by directly killing tumor cells and promoting invasive and metastatic activity $[27,221]$. The first type is M1-like macrophage, which is classically activated and stimulated by bacterial products and alternately activated by cytokines produced by Thelper 1 lymphocyte (Th1). The second is M2-like macrophages (M2a, M2b, M2c, M2d), which inhibit M1 activity and enhance metastasis [185,222,223]. The immune microenvironment plays an important role in determining monocyte/macrophage polarization and tumor progression [223,224]. In addition, within the tumor's protective cells, macrophages are converted to immunosuppressive macrophages of TAM type M2. The different phenotypes of these two macrophages depend on their different markers, gene expression profiles of metabolic properties and microbial signals that represent macrophage polarization [113-115,182,185,217,225-231]. Well-stimulated macrophages can kill tumor cells. However, TME-stimulated TAM lacks the cytotoxic function of macrophages, but they can stimulate tumor activity, cancer-related inflammation, angiogenesis, immunosuppression, tissue remodeling, and metastasis [27,232]. Research has further shown a correlation between the degree of adiposity/obesity and chronic low-grade inflammation, macrophage recruitment, and polarization by stimulating inflammatory pathways, which can lead to increase the risk of cancer $[33,112,233,234]$.

M1-like macrophages activate the type I immune response responsible for protection against intracellular pathogens (antigen presenters) and tumor cells (potentially anti-tumor function) $[19,222,235,236]$. They express high levels of the main histocompatibility complex class II (MHC-II), CD14, CD16, CD68, CD80, and CD86 costimulatory molecules [237-239]. In general, this response is activated by interferon (INF) $-\gamma$, TNF- $\alpha$ or bacterial LPS (microbes or microbial products) $[216,240]$ (Figure 2) and needs a recognition between a specific peptide antigen complex and the MHC of the antigen-presenting cell (usually macrophages). These activated M1s secrete immunostimulants and proinflammatory cytokines such as IFN, IL, and particularly high levels of IL-6, IL-12, IL-23, TNF- $\alpha$, and chemokine ligand (CXCL)-10 [27,241-245] (Figure 3). M1 is characterized by anti-tumor activity because it secretes reactive oxygen species (ROS) and nitrogen intermediates that have cytotoxic effects on tumor cells [181,190,191,222,223,246-253], (Table 1). In addition, some studies have shown a link between obesity and inflammation, which stimulates chronic or mild inflammation of adipose tissue. Obesity inhibits the secretion of the anti-inflammatory adiponectin and increases the secretion of adipokines and pro-inflammatory proteins (TNF- $\alpha$, IL-6, IFN $\gamma$, and TGF- $\beta 1$ ), which enhance overexpression of MHC-II in the primary adipocytes. Such adipocytes will then behave as an antigen presenting cell (APC) to activate the adipose-resident $\mathrm{T}$ cells (ARTs) and stimulate the pro-inflammatory response. Finally, adipocytes can activate T cells and mobilize ATMs directly via the MHC-II pathway and consequently stimulate M1 polarization [254-261]. 


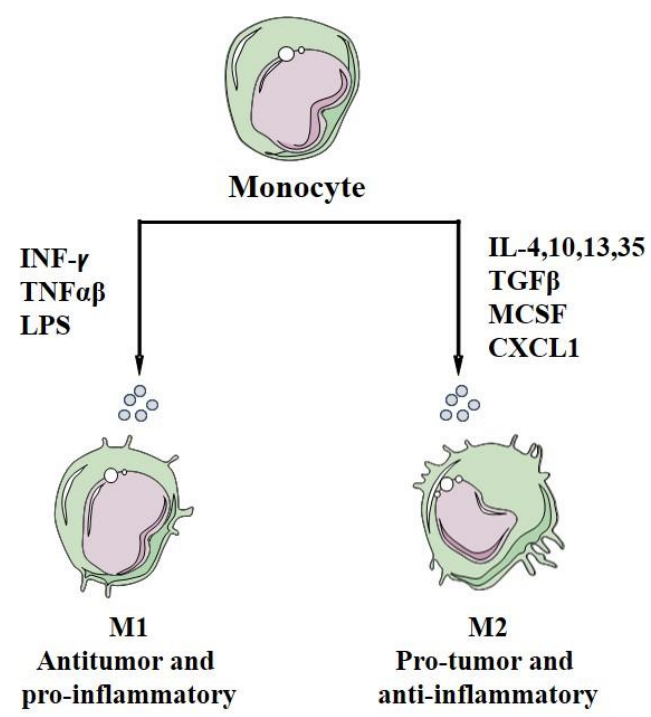

Figure 2. Differentiation of monocytes into macrophages M1 and M2.

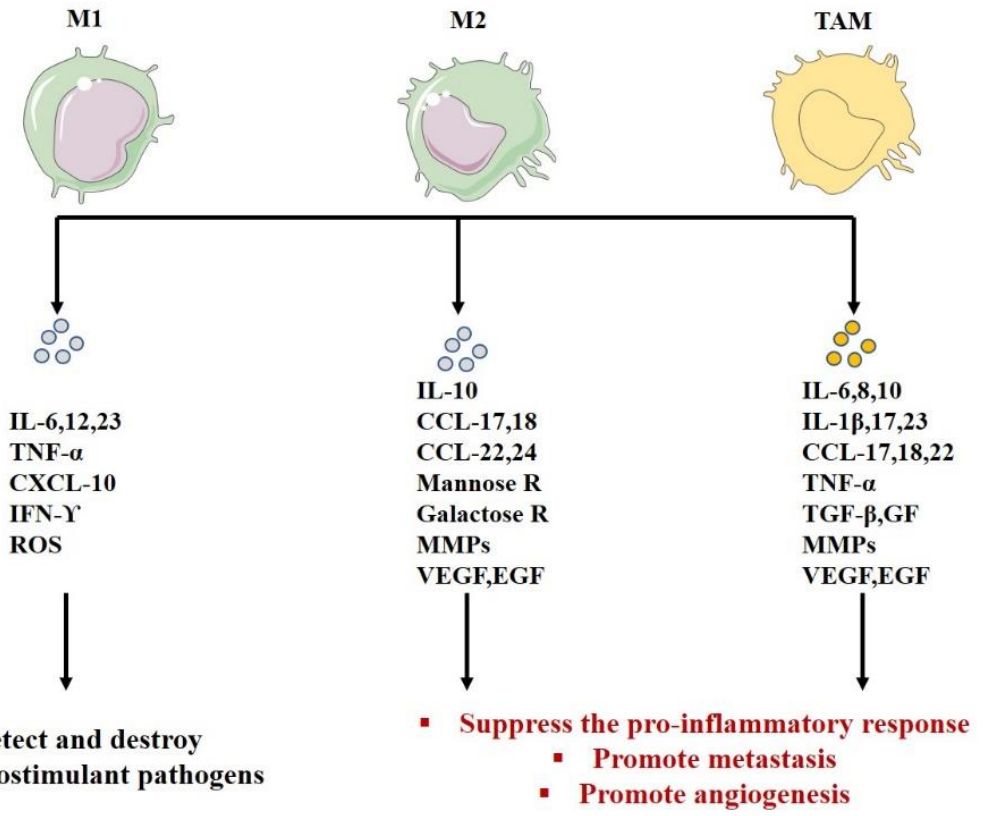

Figure 3. The functions of macrophages M1, M2, and TAMs according to their secretion.

In contrast, M2-like macrophages are activated by immune complexes and cytokines and become the immunosuppressive phenotype $[241,246,262]$ (Figure 2). This population is phenotypically characterized by the expression of the macrophage mannose receptor (MMR), also called CD206. These cells can also be characterized by the expression of CD163 and CD209 [239,263]. They stimulate T helper 2 response, tissue repair, and tumor progression. M2 macrophages are also characterized by hyperphagic activity, high expression of mannose receptor 1 (CD 206), galactose receptors, low levels of IL-12, high expression and secretion of IL-10 [185,217,230], angiogenic factors (VEGF, EGF), and MMPs [182,226-229].

Different subtypes of M2 macrophages can be triggered by different stimulators. They are divided into subpopulations according to the stimuli that activate them, as follows [19,173,264-272]:

1-Alternative M2a macrophages, also called wound healing macrophages, are induced by IL-4 and IL-13. They initiate an immune response by inhibition of Th1 and activation of Th2, thus suppressing and killing parasites. They also secrete fibrosis-promoting factors (TGF- $\beta$, IGF, etc.), IL-10, IL-1ra, promote type II inflammation, kill parasites, and express high levels of CD206, IL-1 receptor, and CCL17. 
2-Regulatory macrophages M2b are activated by immune complexes, LPS, toll-like receptor (TLR) ligands, IL-1b, and physical factors (radiation). When activated, this subtype releases pro-inflammatory and anti-inflammatory cytokines as well as IL1R. In addition, they express high levels of proinflammatory cytokines (such as IL- $1 \beta$, IL-6, TNF- $\alpha$ ), and CCL1. They also express and secrete anti-inflammatory IL-10 and low levels of IL-12 to control metastasis, suppress tumor growth, and induce Th1 responses.

3-Acquired inactivated macrophages M2c are activated by IL-10, TGF- $\beta$, and glucocorticoids, which are responsible for Th1 type reactions. They strongly exhibit antiinflammatory activities by releasing large amounts of IL-10 and secreting high levels of TGF- $\beta$. They are also involved in tissue repair and matrix remodeling.

4-M2d macrophages that represent a new M2 subgroup, also known as tumor-associated macrophages (TAMs), are activated by IL- 6 and adenosines. Adenosines cause the expression of IL-10 and VEGF, leading to angiogenesis and tumor progression. M2d or TAM supports tumor progression by allowing the growth of malignant cell masses and new blood vessels.

TAM is defined as macrophages that invade tumors and are part of the TME. Depending on the type and stage of development of the tumor, it is polarized to M2 and has little ability to present antigens [273]. This subgroup of macrophages often has an anti-inflammatory phenotype. It has been identified in many studies based on biomarkers, such as CD68, CD163, CD204, and/or CD206 [212]. These cells can stimulate tumor growth and metastasis [217,247,265,274,275]. Several microenvironmental cytokines, chemokines, GFs, and other signals from tumors (such as IL-4, IL-10, TGF-1, and prostaglandin E2) and stromal cells stimulate TAM polarization into an M2 phenotype [27,170,276] (Figure 3). We noticed a high TAM density specifically in breast cancer [277] (Table 1). TAMs are promoters of the metastatic stage in the initiation and invasion of tumors [247-251]. They secrete various cytokines (such as IL-23, IL-17, and IL-6), which cause tumor-induced inflammation and promote tumor growth. They also secrete GFs and proteases that stimulate tumor growth and immune regulation $[223,278,279]$. They are mobilized and activated by several signals from TME to promote tumor progression and metastasis [181,223,252]. On the other hand, they suppress the pro-inflammatory response to tumor cells and thus allow their proliferation [223]. TAM improves vascular angiogenesis and metastasis $[14,15,89,90,280]$. It is also involved in the degradation of ECM by the secretion of MMP-2 and MMP-9 [113-115] (Table 1), which depicts the importance of ECM and macrophages in the progression of cancer $[281,282]$. TAM has several partially conflicting activities, both inflammatory and anti-inflammatory, immunostimulatory, anti-immunosuppressive, and tissue-destroying anti-anabolic effects [19,283-293]. It acts in the following three areas of the microenvironment: the infiltration area (enhancing cancer cell migration), the interstitial and perivascular areas (enhancing cancer metastasis), and/or the avascular and perinecrotic areas (where hypoxic TAMs stimulate angiogenesis) [180]. 
Table 1. Comparison between macrophages M1, M2, and TAMs.

\begin{tabular}{|c|c|c|c|c|}
\hline & Macrophage M1 & Macrophage M2 & TAMs & References \\
\hline Cell surface markers & CD14, 16, 68, 80, 86, MHCII & CD14, 163, 206, 209 & CD68, 163, 204, 206 & {$[212,237-239,263]$} \\
\hline Polarization factor & $\begin{array}{c}\text { Polarization of macrophages } \\
\text { to M1 with LPS, IFN, } \\
\text { TNF- } \alpha / \gamma\end{array}$ & $\begin{array}{c}\text { Polarization of macrophages to } \\
\text { M2 with GF, CCL2, CXCL4, } \\
\text { cytokines of Th2 (IL-4, IL-13), } \\
\text { IL-10, IL-35, TGF- } \beta, \text { CXCL } 1 \text { or } \\
\text { corticosteroids. }\end{array}$ & Same to M2s & {$[210-214,217,240,268,276]$} \\
\hline Role & $\begin{array}{c}\text { Detect, destroy } \\
\text { immunostimulant pathogens }\end{array}$ & $\begin{array}{c}\text {-Inhibit lymphocyte functions in } \\
\text { the tumor } \\
\text {-Suppress the pro-inflammatory } \\
\text { response } \\
\text {-Promote tumor progression } \\
\text {-Promote angiogenesis-Degrade } \\
\text { ECM }\end{array}$ & $\begin{array}{c}\text {-Inhibit lymphocyte functions in } \\
\text { the tumor } \\
\text {-Suppress the pro } \\
\text {-inflammatory response } \\
\text {-Promote metastasis-Promote } \\
\text { angiogenesis-Remodel the ECM } \\
\text {-Suppress the adaptive } \\
\text { immunity(M2) }\end{array}$ & {$[181,190,191,222,223,247-253]$} \\
\hline Phenotype & $\begin{array}{l}\text { Pro-inflammatory and tumor } \\
\text { suppressor }\end{array}$ & Pro-tumor (tumor promoter) & Pro-tumor (tumor promoter) & {$[19,210,211,224]$} \\
\hline Cytotoxic activity & $\begin{array}{l}\text { Cytotoxic against } \\
\text { microorganisms and tumor } \\
\text { cells(phagocytosis) }\end{array}$ & $\begin{array}{c}\text { Hyper-phagocytic (promoting } \\
\text { debris trapping) }\end{array}$ & $\begin{array}{c}\text { Hyper-phagocytic (promoting } \\
\text { debris trapping) }\end{array}$ & {$[185,209,268]$} \\
\hline Antigen presentation & High presentation potential & Low presentation potential & Low presentation potential & [216-218] \\
\hline Effect on T lymphocyte & $\begin{array}{l}\text { Produce high levels of Th1 } \\
\text { cell stimulating cytokines }\end{array}$ & $\begin{array}{l}\text { Suppress the proliferation and } \\
\text { action of lymphocytes Th2 cells } \\
\text { (IL-10) }\end{array}$ & $\begin{array}{l}\text { Suppress the proliferation and } \\
\text { action of lymphocytes Th2 cells } \\
\text { (IL-10) }\end{array}$ & {$[19,216,217,265-267]$} \\
\hline Inflammation & Stimulate inflammation & $\begin{array}{l}\text { Negative control of the } \\
\text { inflammatory response } \\
\text { mediated by M1 }\end{array}$ & $\begin{array}{l}\text { Negative control of the } \\
\text { inflammatory response } \\
\text { mediated by M1 }\end{array}$ & {$[216,217]$} \\
\hline Chemokine profiles & $\begin{array}{l}\text { Expressing chemokines } \\
\text { attracting Th1 cells, such as } \\
\text { CXCL9 and CXCL10 }\end{array}$ & $\begin{array}{l}\text { Release of chemokines, CCL17, } \\
\text { CCL22, and CCL24 }\end{array}$ & $\begin{array}{l}\text { Release of chemokines CCL2, } \\
\text { CXCL8, CCL18 (attract subsets } \\
\text { of T cells lacking cytotoxic } \\
\text { function) CCL17 and CCL22 } \\
\text { (promote Th2 in tumors) }\end{array}$ & {$[19,217,225,231,283-293]$} \\
\hline Immune capacity & $\begin{array}{l}\text { Effective cells capable of } \\
\text { killing tumor cells }\end{array}$ & $\begin{array}{l}\text { Promote tissue remodeling and } \\
\text { tumor progression }\end{array}$ & $\begin{array}{l}\text { Promote tissue remodeling, } \\
\text { tumor progression and } \\
\text { metastasis }\end{array}$ & {$[27,209,241,243-246]$} \\
\hline Secretion & $\begin{array}{c}\text { IL-12; IL-1; ROS; IL-23 } \\
\text { CXCL1-3; CXCL5; CXCL8-11 }\end{array}$ & $\begin{array}{c}\text { IL-10 autocrine circuit inhibits } \\
\text { the expression of IL-12 and } \\
\text { IFN- } \gamma \\
\text { CCL17, 18, 22, } 24 \\
\text { Mannose galactose } \\
\text { ReceptorsMMP } \\
\text { VEGF, EGF }\end{array}$ & $\begin{array}{l}\text { IL-10 autocrine circuit inhibits } \\
\text { the expression of IL-12 and } \\
\text { IFN- } \gamma \\
\text { IL-23, IL-17, IL-6 } \\
\text { IL-8, IL-1 } \beta \\
\text { CCL17, } 18,22 \\
\text { VEGF, EGF, TNF- } \alpha \text {, TGF- } \beta \text {, } \\
\text { GFs, MMPs }\end{array}$ & {$[113-115,182,185,217,225-231]$} \\
\hline
\end{tabular}

Besides, adipose tissue macrophages (ATMs) are the major immune cells of the adipose tissue. In general, studies have shown that the phenotype of activated macrophage populations can change occasionally depending on the state of the microenvironment, from classic M1 (anti-tumor) to alternative M2 (protumor), and vice versa [245,294-300].

In the tumor-free adipose matrix, the microenvironment, by secreting soluble factors, stimulates the increase in the expression of inflammatory genes and the decrease in the secretion of anti-inflammatory IL-10 [297,301,302]. This activity results in chronic low-grade inflammation by releasing inflammatory cytokines (TNF- $\alpha$, IL-6, IL-1 $\beta$ and CCL2) that stimulate recruitment and infiltration of macrophages and lymphocytes into the adipose tissue. Consequently, these cells are classically polarized into the M1 phenotype [295-298]. It should be noted that overweight/obesity can stimulate the repolarization of macrophages from the M2 to the M1 phenotype [245,294].

On the other hand, cancer cells in an adipose matrix secrete various cytokines that promote the repolarization of macrophages from an initial M1 profile to a subsequent M2 and TAM profile $[245,299,300]$. Metastasis is then the main stimulator of phenotype repolarization of macrophages from classical activation (M1) to alternative activation (M2) $[168,303]$. The ATMs associated with tumors gain a profile like TAMs to stimulate signaling of cytokine-receptor interactions and free fatty acid production that activates macrophages and vascular endothelial cells. The cancer-related pathways are thus 
overexpressed and the PMN will be more favorable to tumor growth and, consequently, metastasis [100,140-144,295-298,304].

Macrophages also play a major role in anti-cancer therapy resistance. Generally, the function of macrophages leads to sensitization or resistance to traditional therapy. Macrophages have different phenotypes (pro-tumor or anti-tumor) and are important regulators of homeostatic tissue and tumor microenvironments [305]. To improve the response to cytotoxic therapy, various preclinical models are used to stimulate adaptive immune responses by repolarizing macrophages (reprogram to anti-tumor phenotypic states) or blocking macrophage recruitment to tumors (reprogramming them into an antitumor phenotype). This phenomenon has been successful in stimulating the adaptive immune response by either neutralizing the predominant Th2-based program or by directly promoting macrophage activation [306-309]. The polarization of macrophages to M2 mediated the resistance of tumor cells to chemotherapy or radiation therapy and their inhibition showed an improved response to radiation therapy in breast cancer [310]. This transformation induces various cytokines (IL-6, TNF- $\alpha$, EGF, VEGF) [251,311], to improve the proliferation and survival of malignant cells under the treatment, resulting in chemoresistance and radiation defense function [312-314]. Therefore, macrophages support T cell responses, limit sustained tumor growth along with cytotoxic therapy, and validate their consideration in tumor immunotherapy. Diverse drugs had some success and received clinical approval from the FDA to targeting malignant cells (with EGFR inhibitors and HER2-targeted drugs) [315-317] and nonmalignant cells such as cellular and molecular components of TME function.

\section{Angiogenesis and Hypoxia}

Angiogenesis is the first step involved in the appearance of metastases. In 1971, Dr. Judah Folkman suggested that tumor metastasis, progression, and enlargement (limited to 1 or $2 \mathrm{~mm}$ ) are dependent on angiogenic regulators [179]. Various experimental studies have been conducted to show the role of alternately activated macrophages (M2, TAM) and adipocytes, which are major effectors in tumor progression [188,318-324] through different pathways, such as interstitial increased deposit [217,324-326], angiogenesis [327-330], and eventually, metastasis [100,190,217,265,291,297,301,302,304,326]. Blood and lymph networks are also involved in the supply of oxygen and nutrients to maintain cell survival and growth, or in the immune surveillance at the stage of tumor development. The angiogenic switch is a dramatic improvement in the vascular density process supported by various mediators produced by neoplastic and stromal cells. It regulates tumor vascular programming, which induces high-density angiogenesis and increases nutrient uptake and waste removal [331,332]. This switch is in the process of continuous growth of new blood vessels and remains activated almost all the time during tumor angiogenesis. Existing intra-tumor blood vessels and infiltrative foreheads form a cluster of new blood vessels surrounding the tumor. Such vessels are mostly ineffective, twisted or permeable [231,322,333-336]. In general, angiogenesis is activated by tumors (at a particular tumor size) to promote metastasis [322,324,337] (Figure 4). The formation of a complete vasculature is considered a complex process involving many cell types, often with overlapping functions that affect tumor outcomes, such as TAM and CAA cells, which express many factors that intervene in this process, citing the following: 


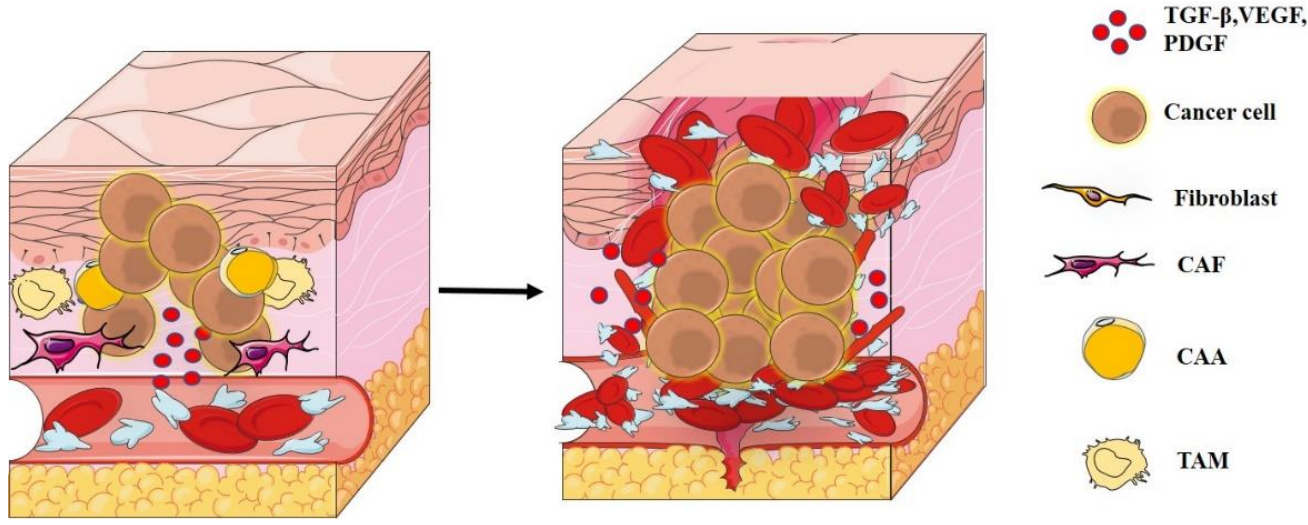

Figure 4. Brief description of tumor angiogenesis.

1-Angiogenesis-promoting factors such as TGF- $\beta$, VEGF, and PDGF that increase the density of microvessels, reverse the effects of angiogenesis, promote macrophages, and stimulate invasion into tumors and metastases [19,188,200,318-324]. On the other hand, their loss leads to the normalization of blood vessels [299,300,321,338,339].

2-Cytokines, GFs, and activated myofibroblasts that stimulate the deposition of fibers in the interstitium and create a coagulation-promoting state, improving the formation of indirect blood vessels [217,324-326].

3-MMPs such as MMP2, MMP7, MMP9, and MMP12 that mediate bioavailability (MMP9) and activate TGF- $\beta$ (MMP2) to promote angiogenesis $[17,37,108-110,120-122,140-$ $144,306,312,320,321]$.

4-Various chemokines CXCL1, CXCL8, CXCL12, CXCL13, CCL2, CCL5 [100,265,297, 301,302,304,326].

Besides, hypoxia, a phenomenon associated with hypoxic partial pressure, is usually an important factor in improving angiogenesis. Cell proliferation in cancer is known to require a lot of energy, and therefore oxygen, to progress. When intratumorally, $\mathrm{O}_{2}$ is reduced, the HIF-1 protein then helps form new blood vessels for $\mathrm{O}_{2}$ supply. HIF-1 proteins act as transcription factors in all tissues and are regulated by $\mathrm{O}_{2}$ deficiency $[322,323]$. This protein was discovered in 1992 by Gregg L. Semenza, who studied the EPO gene. Tissue with hypoxia is usually treated by stimulating EPO production, which induces red blood cell production, resulting in improved transport of $\mathrm{O}_{2}$ to the target tissue. The low intratumor oxygen level helps HIF-1 proteins form new blood vessels for oxygen supply [323,324].

On the other hand, advanced TME is characterized by a strong metabolism and a high tumor growth level $[325,326]$. In solid tumors, peripheral blood vessels become hypoxic due to inadequate oxygen supply. In contrast, primary tumor cells are highly flexible and can quickly adapt to hypoxic content or migrate to blood vessels to promote tumor growth $[323,324,326-328]$. The tumors then show a strong tendency to metastasize. In addition, hypoxia polarizes macrophage phenotypes to a protumor profile M2 through lactate secretion. Lactic acid is released from anaerobic glycolysis of tumor cells in the region of hypoxic partial pressure [322,329]. Hypoxia is also a vital regulator of immune recruitment, by promoting the behavior of malignant tumors, promoting glycolysis and cell differentiation, inhibiting apoptosis, and reducing therapeutic efficacy [275,330-333]. In hypoxia, chemokinesis secretions (CCL2) recruit macrophages to the hypoxic region of the tumor, where they accumulate. Their accumulation in the hypoxic region leads to aggressive tumor behavior [179,302,334,335]. Normally, due to hypoxia and overexpression of HIF-1, TAM inhibits effector T cells by secreting immunosuppressive cytokines (IL-10) [336] and stimulating angiogenesis around cancer necrosis and angiogenesis. Moreover, it expresses VEGF and TAM in the region of cancer $[188,337,338]$ and produces various cytokines (such as IL-23 and IL-17 that cause tumor-induced inflammation and promote tumor growth, GF, and proteases to enhance tumor growth, angiogenesis, immune regulation, 
and metastasis) $[223,278,279]$. Macrophages and adipocytes can secrete VEGF, but in other cases, the VEGF becomes biologically available through the production of MMP9, which degrades ECM, resulting in collagen-encapsulated VEGF [37,107-110].

Radiotherapy, chemotherapy, and immunotherapy are the mainstays of cancer treatment. Immunotherapy strategies targeting nonmalignant cells have been developed, including the following: (a) antiangiogenic drugs (neutralizing antibody targeting VEGF) [340-343], (b) drugs targeting TAMs (emactuzumab), which contribute to chemoresistance by inducing prosurvival and antiapoptotic signals in cancer cells [344,345], (c) anti-cachexia drugs (thalidomide and megestrol acetate to downregulate IL-6 and TNF- $\alpha$ production) [346], (d) adoptive cellular immunotherapy (by transferring specific immune cells to the tumorbearing host) [347], (e) antibodies (rituximab and trastuzumab) [348,349], (f) small-molecule inhibitors (synergistic with other immune-oncology therapies to suppress tumors by targeting macrophage-associated molecules) [350], (g) immune checkpoint inhibitors (blocking immunocytokines and the PD-1/PD-L1 pathways with inhibitors to enhance the cytotoxic function of T cells) [351] and (h) multiple agents targeting Th2 cytokines and their receptors (targeting IL-4, IL-13, IL-4R $\alpha$ ) [352,353].

\section{Conclusions}

The microenvironment of inflammatory adipose tissue is rich in multiple types of cells, including inflammatory cells and stromal cells. Adipocytes and macrophages indirectly work together to create a classic low-grade, anti-tumor inflammatory condition. This inflammation results from a pro-inflammatory dialogue between adipocytes and immune cells. However, there are several mechanisms in adipose tissue that produce chronic lowgrade inflammation. Adipocytes activate the inflammatory response, increase adipocyte IL-10, weaken inflammatory ATM polarization, activate ART proliferation, stimulate ATM accumulation and polarization, and escalate fat inflammation as an APC. Adipocytes could mimic the role of macrophages. These same cells in EMT create an anti-inflammatory phenotype and prevent the anti-tumor immune response cells from reaching the cancer site. Adipocytes, macrophages, and tumor cells can then regulate several important signaling pathways to create a microenvironment that promotes cancer progression and metastasis. According to current studies, cancer cells degrade ECM, activate myofibroblasts, mobilize immune cells into tumors, and secrete various cytokines and GFs that differentiate, activate, and polarize macrophages into TAM and M2. These cells are preferably destined to meet the needs of cancer cells in a pro-tumor function (M2) instead of a pro-inflammatory anticancer function (M1) and enhance their malignant behavior towards tumor metastasis. Macrophages play an important role in tumors. Depending on the mode of activation, they can promote tumor growth, suppress local immunity, attack tumor cells, and even maintain tumor immunity. To decipher such complex functions requires a good understanding of how different macrophage subsets of human tumors interact with adipocytes in overweight and obese people. For this reason, cancer is a malignant disease that reverses the normal function of protective cells to promote metastasis that normally occurs in most patients. On the other hand, the details of the molecules and cells involved in promoting metastasis can be more complex than we expect. Recently, various three-dimensional (3D) in vitro models used the macrophage phenotype of stromal cells to describe regulators involved in ECM degradation, metastasis, recruitment, and macrophage polarization in the adipose matrix. Cells develop in an organized 3D matrix whose behavior depends on their interaction with adjacent cells and the ECM. A 3D culture is an important tool for better understanding changes and interactions between macrophage phenotypes during molecular signaling of malignant transformation and metastasis. 
Author Contributions: Conceptualisation, O.H. and L.D.; Writing-original draft preparation, O.H.; writing and editing, L.D., M.D.-A. and F.C.-C. All authors have read and agreed to the published version of the manuscript.

Funding: This research received no external funding.

Institutional Review Board Statement: Not applicable.

Informed Consent Statement: Not applicable.

Data Availability Statement: Not applicable.

Conflicts of Interest: The authors have no financial disclosures to make or conflicts to report.

\begin{abstract}
Abbreviations
ASC: adipose stem cell; APC: antigen presenting cell; ART: adipose-resident T-cell; ATM: adipose tissue macrophage; CAA: cancer-associated adipocyte; CAF: cancer-associated fibroblast; MDSC: myeloid-derived suppressor cell; M-MDSC: myeloid MDSC; G-MDSC: granulocytic MDSC; CCL: chemokine ligand; ECM: extracellular matrix; EGF: epidermal growth factor; EMT: epithelialmesenchymal transition; FN: fibronectin; GF: growth factor; HIF: hypoxia inducible factor; IL: interleukin; LOX: lysyl oxidase; MMP: matrix metalloproteinase; $\mathrm{O}_{2}$ : dioxygen; PMN: pre-metastatic niche; ROS: reactive oxygen species; TAM: tumor-associated macrophage; TGF: transformative growth factor; Th1: T helper1 lymphocyte; TME: tumor microenvironment; TNF: tumor necrosis factor; WAT: white adipocyte tissue; EPO: Erythropoietin.
\end{abstract}

\title{
References
}

1. Ferlay, J.; Soerjomataram, I.; Dikshit, R.; Eser, S.; Mathers, C.; Rebelo, M.; Donald Maxwell, P.; Forman, D.; Bray, F. Cancer incidence and mortality worldwide: Sources, methods and major patterns in GLOBOCAN 2012. Int. J. Cancer 2015, 136, E359-E386. [CrossRef]

2. Hanahan, D.; Weinberg, R.A. Hallmarks of Cancer: The Next Generation. Cell 2011, 144, 646-674. [CrossRef] [PubMed]

3. Wang, Y.; Mo, Y.; Zhaojian, G.; Yang, X.; Yang, M.; Zhang, S.; Xiang, F.; Xiang, B.; Zhou, M.; Liao, Q.; et al. Circular RNAs in human cancer. Mol. Cancer 2017, 16, 1-8. [CrossRef] [PubMed]

4. Wyckoff, J.; Wang, W.; Lin, E.Y.; Wang, Y.; Pixley, F.; Stanley, E.R.; Graf, T.; Pollard, J.W.; Segall, J.; Condeelis, J.; et al. A paracrine loop between tumor cells and macrophages is required for tumor cell migration in mammary tumors. Cancer Res. 2004, 64, 7022-7029. [CrossRef]

5. Gupta, G.P.; Massague, J. Cancer Metastasis: Building a Framework. Cell 2006, 127, 679-695. [CrossRef] [PubMed]

6. Chaffer, C.L.; Weinberg, R.A. A Perspective on Cancer Cell Metastasis. Science 2011, 331, 1559-1564. [CrossRef]

7. Chambers, A.F.; Groom, A.C.; Macdonald, I.C. Dissemination and growth of cancer cells in metastatic sites. Nat. Cancer 2002, 2, 563-572. [CrossRef]

8. Seyfried, T.N.; Huysentruyt, L.C. On the Origin of Cancer Metastasis. Crit. Rev. Oncog. 2013, 18, 43-73. [CrossRef]

9. Guan, X. Cancer metastases: Challenges and opportunities. Acta Pharm. Sin. B 2015, 5, 402-418. [CrossRef]

10. Paget, S. The distribution of secondary growths in cancer of the breast. Cancer Metastasis Rev. 1989, 8, 98-101. [CrossRef]

11. Joyce, J.A.; Pollard, J.W. Microenvironmental regulation of metastasis. Nat. Cancer 2008, 9, 239-252. [CrossRef]

12. Kaplan, R.N.; Riba, R.D.; Zacharoulis, S.; Bramley, A.H.; Vincent, L.; Costa, C.; MacDonald, D.D.; Jin, D.K.; Shido, K.; Kerns, S.A.; et al. VEGFR1-positive haematopoietic bone marrow progenitors initiate the pre-metastatic niche. Nature 2005, 438, 820-827. [CrossRef]

13. Chen, F.; Zhuang, X.; Lin, L.; Yu, P.; Wang, Y.; Shi, Y.; Hu, G.; Sun, Y. New horizons in tumor microenvironment biology: Challenges and opportunities. BMC Med. 2015, 13, 45. [CrossRef]

14. Butcher, D.T.; Alliston, T.; Weaver, V.M. A tense situation: Forcing tumour progression. Nat. Cancer 2009, 9, 108-122. [CrossRef]

15. Paszek, M.J.; Zahir, N.; Johnson, K.R.; Lakins, J.N.; Rozenberg, G.I.; Gefen, A.; Reinhart-King, C.A.; Margulies, S.S.; Dembo, M.; Boettiger, D.; et al. Tensional homeostasis and the malignant phenotype. Cancer Cell 2005, 8, 241-254. [CrossRef]

16. Levental, K.; Yu, H.; Kass, L.; Lakins, J.N.; Egeblad, M.; Erler, J.T.; Fong, S.F.; Csiszar, K.; Giaccia, A.; Weninger, W.; et al. Matrix Crosslinking Forces Tumor Progression by Enhancing Integrin Signaling. Cell 2009, 139, 891-906. [CrossRef]

17. Lewis, C.; Leek, R.; Harris, A.; McGee, J. Cytokine regulation of angiogenesis in breast cancer: The role of tumor-associated macrophages. J. Leukoc. Biol. 1995, 57, 747-751. [CrossRef]

18. Sica, A.; Allavena, P.; Mantovani, A. Cancer related inflammation: The macrophage connection. Cancer Lett. 2008, 267, 204-215. [CrossRef]

19. Solinas, G.; Germano, G.; Mantovani, A.; Allavena, P. Tumor-associated macrophages (TAM) as major players of the cancer-related inflammation. J. Leukoc. Biol. 2009, 86, 1065-1073. [CrossRef] 
20. Balkwill, F.; Mantovani, A. Inflammation and cancer: Back to Virchow? Lancet 2001, 357, 539-545. [CrossRef]

21. Gordon, S.; Martinez, F.O. Alternative Activation of Macrophages: Mechanism and Functions. Immunity 2010, 32, 593-604. [CrossRef]

22. Leek, R.D.; Harris, A. Tumor-Associated Macrophages in Breast Cancer. J. Mammary Gland. Biol. Neoplasia 2002, 7, 177-189. [CrossRef]

23. Wynn, T.A.; Chawla, A.; Pollard, J.W. Macrophage biology in development, homeostasis and disease. Nature 2013, 496, 445-455. [CrossRef]

24. Davis, C.D.; Milner, J.A. Molecular Targets for Nutritional Preemption of Cancer. Curr. Cancer Drug Targets 2007, 7, 410-415. [CrossRef]

25. Biswas, S.K.; Sica, A.; Lewis, C.E. Plasticity of Macrophage Function during Tumor Progression: Regulation by Distinct Molecular Mechanisms. J. Immunol. 2008, 180, 2011-2017. [CrossRef]

26. McGregor, D.D.; Koster, F.T.; Mackaness, G.B. Biological Sciences: The Short Lived Small Lymphocyte as a Mediator of Cellular Immunity. Nature 1970, 228, 855-856. [CrossRef]

27. Qian, B.-Z.; Pollard, J.W. Macrophage Diversity Enhances Tumor Progression and Metastasis. Cell 2010, 141, 39-51. [CrossRef]

28. Schoemaker, M.J.; Nichols, H.B.; Wright, L.B.; Brook, M.N.; Jones, M.E.; O’Brien, K.M.; Adami, H.; Baglietto, L.; Bernstein, L.; Bertrand, K.A.; et al. Association of Body Mass Index and Age with Subsequent Breast Cancer Risk in Premenopausal Women. JAMA Oncol. 2018, 4, e181771. [CrossRef]

29. Olefsky, J.M.; Glass, C.K. Macrophages, Inflammation, and Insulin Resistance. Annu. Rev. Physiol. 2010, 72, 219-246. [CrossRef]

30. Hotamisligil, G.S.; Shargill, N.S.; Spiegelman, B.M. Adipose Expression of Tumor Necrosis Factor- $\alpha$ : Direct Role in Obesity-Linked Insulin Resistance. Science 1993, 259, 87-91. [CrossRef]

31. Weisberg, S.P.; McCann, D.; Desai, M.; Rosenbaum, M.; Leibel, R.L.; Ferrante, A.W. Obesity is associated with macrophage accumulation in adipose tissue. J. Clin. Investig. 2003, 112, 1796-1808. [CrossRef]

32. Hruskova, Z.; Biswas, S.K. A New "Immunological" Role for Adipocytes in Obesity. Cell Metab. 2013, 17, 315-317. [CrossRef]

33. Key, T.J.; Appleby, P.N.; Reeves, G.K.; Roddam, A.; Dorgan, J.F.; Longcope, C.; Stanczyk, F.Z.; Stephenson, H.E., Jr.; Falk, R.T.; Miller, R.; et al. Body mass index, serum sex hormones, and breast cancer risk in postmenopausal women. J. Natl. Cancer Inst. 2003, 95, 1218-1226. [CrossRef]

34. Parekh, N.; Chandran, U.; Bandera, E.V. Obesity in Cancer Survival. Annu. Rev. Nutr. 2012, 32, 311-342. [CrossRef]

35. Donohoe, C.; O'Farrell, N.J.; Doyle, S.L.; Reynolds, J.V. The role of obesity in gastrointestinal cancer: Evidence and opinion. Ther Adv. Gastroenterol. 2013, 7, 38-50. [CrossRef]

36. Järveläinen, H.; Sainio, A.; Koulu, M.; Wight, T.N.; Penttinen, R. Extracellular matrix molecules: Potential targets in pharmacotherapy. Pharmacol. Rev. 2009, 61, 198-223. [CrossRef]

37. Bonnans, C.; Chou, J.; Werb, Z. Remodelling the extracellular matrix in development and disease. Nat. Rev. Mol. Cell Biol. 2014, 15, 786-801. [CrossRef]

38. Frantz, C.; Stewart, K.M.; Weaver, V.M. The extracellular matrix at a glance. J. Cell Sci. 2010, 123, 4195-4200. [CrossRef]

39. Habanjar, O.; Diab-Assaf, M.; Caldefie-Chezet, F.; Delort, L. 3D Cell Culture Systems: Tumor Application, Advantages, and Disadvantages. Int. J. Mol. Sci. 2021, 22, 12200. [CrossRef]

40. Lu, P.; Weaver, V.M.; Werb, Z. The extracellular matrix: A dynamic niche in cancer progression. J. Cell Biol. 2012, 196, 395-406. [CrossRef]

41. Ricard-Blum, S. The Collagen Family. Cold Spring Harb. Perspect. Biol. 2011, 3, a004978. [CrossRef]

42. Hashmi, S.; Marinkovich, M.P. Molecular organization of the basement membrane zone. Clin. Dermatol. 2011, $29,398-411$. [CrossRef]

43. Hohenester, E.; Yurchenco, P. Laminins in basement membrane assembly. Cell Adhes. Migr. 2013, 7, 56-63. [CrossRef]

44. Mouw, J.K.; Ou, G.; Weaver, V.M. Extracellular matrix assembly: A multiscale deconstruction. Nat. Rev. Mol. Cell Biol. 2014, 15, 771-785. [CrossRef]

45. Raab-Westphal, S.; Marshall, J.F.; Goodman, S.L. Integrins as Therapeutic Targets: Successes and Cancers. Cancers 2017, 9, 110. [CrossRef]

46. Chen, K.D.; Li, Y.S.; Kim, M.; Li, S.; Yuan, S.; Chien, S.; Shyy, J.Y. Mechanotransduction in response to shear stress. Roles of receptor tyrosine kinases, integrins, and Shc. J. Biol. Chem. 1999, 274, 18393-18400. [CrossRef]

47. Katsumi, A.; Orr, A.; Tzima, E.; Schwartz, M.A. Integrins in Mechanotransduction. J. Biol. Chem. 2004, 279, 12001-12004. [CrossRef]

48. Huveneers, S.; Danen, E.H.J. Adhesion signaling-Crosstalk between integrins, Src and Rho. J. Cell Sci. 2009, 122, 1059-1069. [CrossRef]

49. Dupont, S. Role of YAP/TAZ in cell-matrix adhesion-mediated signalling and mechanotransduction. Exp. Cell Res. 2016, 343, 42-53. [CrossRef]

50. Harburger, D.S.; Calderwood, D.A. Integrin signalling at a glance. J. Cell Sci. 2009, 122, 159-163. [CrossRef]

51. Humphries, J.D.; Byron, A.; Humphries, M.J. Integrin ligands at a glance. J. Cell Sci. 2006, 119, 3901-3903. [CrossRef]

52. Myllyharju, J.; Kivirikko, K.I. Collagens, modifying enzymes and their mutations in humans, flies and worms. Trends Genet. 2004, 20, 33-43. [CrossRef] 
53. Ricard-Blum, S.; Ruggiero, F. The collagen superfamily: From the extracellular matrix to the cell membrane. Pathol. Biol. 2005, 53, 430-442. [CrossRef]

54. Rozario, T.; DeSimone, D.W. The extracellular matrix in development and morphogenesis: A dynamic view. Dev. Biol. 2010, 341, 126-140. [CrossRef]

55. Camenisch, T.D.; Spicer, A.P.; Brehm-Gibson, T.; Biesterfeldt, J.; Augustine, M.L.; Calabro, A., Jr.; Kubalak, S.; Klewer, S.E.; McDonald, J.A. Disruption of hyaluronan synthase-2 abrogates normal cardiac morphogenesis and hyaluronan-mediated transformation of epithelium to mesenchyme. J. Clin. Investig. 2000, 106, 349-360. [CrossRef]

56. Hynes, R.O. The extracellular matrix: Not just pretty fibrils. Science 2009, 326, 1216-1219. [CrossRef]

57. Bosman, F.T.; Stamenkovic, I. Functional structure and composition of the extracellular matrix. J. Pathol. 2003, 200, 423-428. [CrossRef]

58. Zhu, J.; Liang, L.; Jiao, Y.; Liu, L. Enhanced invasion of metastatic cancer cells via extracellular matrix interface. PLoS ONE 2015, 10, e0118058. [CrossRef]

59. Singh, P.; Carraher, C.; Schwarzbauer, J.E. Assembly of Fibronectin Extracellular Matrix. Annu. Rev. Cell Dev. Biol. 2010, 26, 397-419. [CrossRef]

60. Dallas, S.L.; Sivakumar, P.; Jones, C.J.P.; Chen, Q.; Peters, D.M.; Mosher, D.F.; Humphries, M.J.; Kielty, C.M. Fibronectin regulates latent transforming growth factor-beta (TGF beta) by controlling matrix assembly of latent TGF beta-binding protein-1. J. Biol. Chem. 2005, 280, 18871-18880. [CrossRef]

61. Sottile, J.; Hocking, D.C. Fibronectin Polymerization Regulates the Composition and Stability of Extracellular Matrix Fibrils and Cell-Matrix Adhesions. Mol. Biol. Cell 2002, 13, 3546-3559. [CrossRef] [PubMed]

62. Dzamba, B.J.; Wu, H.; Jaenisch, R.; Peters, D.M. Fibronectin binding site in type I collagen regulates fibronectin fibril formation. J. Cell Biol. 1993, 121, 1165-1172. [CrossRef] [PubMed]

63. Colombi, M.; Zoppi, N.; De Petro, G.; Marchina, E.; Gardella, R.; Tavian, D.; Ferraboli, S.; Barlati, S. Matrix assembly induction and cell migration and invasion inhibition by a 13-amino acid fibronectin peptide. J. Biol. Chem. 2003, 278, 14346-14355. [CrossRef] [PubMed]

64. Tsang, K.Y.; Cheung, M.C.H.; Chan, D.; Cheah, K.S.E. The developmental roles of the extracellular matrix: Beyond structure to regulation. Cell Tissue Res. 2010, 339, 93-110. [CrossRef]

65. Friedl, P.; Wolf, K. Tube Travel: The Role of Proteases in Individual and Collective Cancer Cell Invasion. Cancer Res. 2008, 68, 7247-7249. [CrossRef]

66. Gritsenko, P.G.; Ilina, O.; Friedl, P. Interstitial guidance of cancer invasion. J. Pathol. 2012, 226, 185-199. [CrossRef]

67. Deberardinis, R.J.; Sayed, N.; Ditsworth, D.; Thompson, C.B. Brick by brick: Metabolism and tumor cell growth. Curr. Opin. Genet. Dev. 2008, 18, 54-61. [CrossRef]

68. Cox, T.R.; Erler, J.T. Remodeling and homeostasis of the extracellular matrix: Implications for fibrotic diseases and cancer. Dis. Model. Mech. 2011, 4, 165-178. [CrossRef]

69. Schäfer, M.; Werner, S. Cancer as an overhealing wound: An old hypothesis revisited. Nat. Rev. Mol. Cell Biol. 2008, 9, 628-638. [CrossRef]

70. Sleeman, J.P. The lymph node pre-metastatic niche. J. Mol. Med. 2015, 93, 1173-1184. [CrossRef]

71. Ordóñez-Morán, P.; Huelsken, J. Complex metastatic niches: Already a target for therapy? Curr. Opin. Cell Biol. 2014, 31, 29-38. [CrossRef] [PubMed]

72. Chronopoulos, A.; Robinson, B.; Sarper, M.; Cortes, E.; Auernheimer, V.; Lachowski, D.; Attwood, S.; García, R.; Ghassemi, S.; Fabry, B.; et al. ATRA mechanically reprograms pancreatic stellate cells to suppress matrix remodelling and inhibit cancer cell invasion. Nat. Commun. 2016, 7, 12630. [CrossRef] [PubMed]

73. Psaila, B.; Lyden, D. The metastatic niche: Adapting the foreign soil. Nat. Cancer 2009, 9, 285-293. [CrossRef] [PubMed]

74. Quail, D.F.; Joyce, J.A. Microenvironmental regulation of tumor progression and metastasis. Nat. Med. 2013, 19, 1423-1437. [CrossRef] [PubMed]

75. Hiratsuka, S.; Watanabe, A.; Aburatani, H.; Maru, Y. Tumour-mediated upregulation of chemoattractants and recruitment of myeloid cells predetermines lung metastasis. Nat. Cell Biol. 2006, 8, 1369-1375. [CrossRef] [PubMed]

76. Dirat, B.; Bochet, L.; Dabek, M.; Daviaud, D.; Dauvillier, S.; Majed, B.; Wang, Y.Y.; Meulle, A.; Salles, B.; Le Gonidec, S.; et al. Cancer-associated adipocytes exhibit an activated phenotype and contribute to breast cancer invasion. Cancer Res. 2011, 71, 2455-2465. [CrossRef] [PubMed]

77. Malik, R.; Lelkes, P.I.; Cukierman, E. Biomechanical and biochemical remodeling of stromal extracellular matrix in cancer. Trends Biotechnol. 2015, 33, 230-236. [CrossRef]

78. Corrêa, L.H.; Corrêa, R.; Farinasso, C.M.; Dourado, L.P.D.S.; Magalhães, K.G. Adipocytes and Macrophages Interplay in the Orchestration of Tumor Microenvironment: New Implications in Cancer Progression. Front. Immunol. 2017, 8, 1129. [CrossRef]

79. Discher, D.E.; Mooney, D.J.; Zandstra, P.W. Growth Factors, Matrices, and Forces Combine and Control Stem Cells. Science 2009, 324, 1673-1677. [CrossRef]

80. Calvo, F.; Ege, N.; Grande-Garcia, A.; Hooper, S.; Jenkins, R.P.; Chaudhry, S.I.; Harrington, K.; Williamson, P.; Moeendarbary, E.; Charras, G.; et al. Mechanotransduction and YAP-dependent matrix remodelling is required for the generation and maintenance of cancer-associated fibroblasts. Nat. Cell Biol. 2013, 15, 637-646. [CrossRef] 
81. Varelas, X. The Hippo pathway effectors TAZ and YAP in development, homeostasis and disease. Development 2014, 141, 1614-1626. [CrossRef] [PubMed]

82. Xiao, Q.; Ge, G. Lysyl oxidase, extracellular matrix remodeling and cancer metastasis. Cancer Microenviron. Off. J. Int. Cancer Microenviron. Soc. 2012, 5, 261-273. [CrossRef] [PubMed]

83. Paszek, M.J.; Weaver, V.M. The Tension Mounts: Mechanics Meets Morphogenesis and Malignancy. J. Mammary Gland Biol. Neoplasia 2004, 9, 325-342. [CrossRef] [PubMed]

84. De Wever, P.O.; Demetter, M.M.; Bracke, M. Stromal myofibroblasts are drivers of invasive cancer growth. Int. J. Cancer 2008, 123, 2229-2238. [CrossRef]

85. Desmouliere, A.; Guyot, C.; Gabbiani, G. The stroma reaction myofibroblast: A key player in the control of tumor cell behavior. Int. J. Dev. Biol. 2004, 48, 509-517. [CrossRef]

86. Kalluri, R.; Zeisberg, M. Fibroblasts in cancer. Nat. Rev. Cancer 2006, 6, 392-401. [CrossRef]

87. Wiseman, B.S.; Werb, Z. Stromal effects on mammary gland development and breast cancer. Science 2002, 296, 1046-1049. [CrossRef]

88. Fukui, H.; Zhang, X.; Sun, C.; Hara, K.; Kikuchi, S.; Yamasaki, T.; Kondo, T.; Tomita, T.; Oshima, T.; Watari, J.; et al. IL-22 produced by cancer-associated fibroblasts promotes gastric cancer cell invasion via STAT3 and ERK signaling. Br. J. Cancer 2014, 111, 763-771. [CrossRef]

89. Erler, J.T.; Weaver, V.M. Three-dimensional context regulation of metastasis. Clin. Exp. Metastasis 2009, 26, 35-49. [CrossRef]

90. Nurmik, M.; Ullmann, P.; Rodriguez, F.; Haan, S.; Letellier, E. In search of definitions: Cancer-associated fibroblasts and their markers. Int. J. Cancer 2020, 146, 895-905. [CrossRef]

91. Lucero, H.A.; Kagan, H.M. Lysyl oxidase: An oxidative enzyme and effector of cell function. Cell. Mol. Life Sci. C 2006, 63, 2304-2316. [CrossRef] [PubMed]

92. Rodriguez, C.; Rodríguez-Sinovasm, A.; Martínez-González, J. Lysyl oxidase as a potential therapeutic target. Drug News Perspect. 2008, 21, 218-224. [CrossRef] [PubMed]

93. Conklin, M.W.; Eickhoff, J.C.; Riching, K.M.; Pehlke, C.A.; Eliceiri, K.W.; Provenzano, P.P.; Friedl, A.; Keely, P.J. Aligned Collagen Is a Prognostic Signature for Survival in Human Breast Carcinoma. Am. J. Pathol. 2011, 178, 1221-1232. [CrossRef] [PubMed]

94. Riching, K.M.; Cox, B.L.; Salick, M.R.; Pehlke, C.; Riching, A.S.; Ponik, S.M.; Bass, B.R.; Crone, W.C.; Jiang, Y.; Weaver, A.M.; et al. 3D collagen alignment limits protrusions to enhance breast cancer cell persistence. Biophys. J. 2014, 107, 2546-2558. [CrossRef] [PubMed]

95. Liotta, L.A.; Kohn, E.C. The microenvironment of the tumour-host interface. Nature 2001, 411, 375-379. [CrossRef]

96. Rajala, M.W.; Scherer, P.E. Minireview: The Adipocyte-At the Crossroads of Energy Homeostasis, Inflammation, and Atherosclerosis. Endocrinology 2003, 144, 3765-3773. [CrossRef]

97. Braun, S.; Bitton-Worms, K.; Leroith, D. The Link between the Metabolic Syndrome and Cancer. Int. J. Biol. Sci. 2011, 7, 1003-1015. [CrossRef]

98. Hoy, A.J.; Balaban, S.; Saunders, D. Adipocyte-Tumor Cell Metabolic Crosstalk in Breast Cancer. Trends Mol. Med. 2017, 23, 381-392. [CrossRef]

99. Thomou, T.; Mori, M.A.; Dreyfuss, J.M.; Konishi, M.; Sakaguchi, M.; Wolfrum, C.; Rao, T.N.; Winnay, J.N.; Garcia-Martin, R.; Grinspoon, S.K.; et al. Adipose-derived circulating miRNAs regulate gene expression in other tissues. Nature 2017, 542, 450-455. [CrossRef]

100. Santander, A.M.; Lopez-Ocejo, O.; Casas, O.; Agostini, T.; Sanchez, L.; Lamas-Basulto, E.; Carrio, R.; Cleary, M.P.; Gonzalez-Perez, R.R.; Torroella-Kouri, M. Paracrine Interactions between Adipocytes and Tumor Cells Recruit and Modify Macrophages to the Mammary Tumor Microenvironment: The Role of Obesity and Inflammation in Breast Adipose Tissue. Cancers 2015, 7, 143-178. [CrossRef]

101. Bougaret, L.; Delort, L.; Billard, H.; Lequeux, C.; Goncalves-Mendes, N.; Mojallal, A.; Damour, O.; Vasson, M.P.; Caldefie-Chezet, F. Supernatants of Adipocytes from Obese Versus Normal Weight Women and Breast Cancer Cells: In Vitro Impact on Angiogenesis. J. Cell. Physiol. 2017, 232, 1808-1816. [CrossRef]

102. Bougaret, L.; Delort, L.; Billard, H.; Le Huede, C.; Boby, C.; De la Foye, A.; Rossary, A.; Mojallal, A.; Damour, O.; Auxenfans, C.; et al. Adipocyte/breast cancer cell crosstalk in obesity interferes with the anti-proliferative efficacy of tamoxifen. PLoS ONE 2018, 13, e0191571. [CrossRef] [PubMed]

103. Iyengar, N.M.; Gucalp, A.; Dannenberg, A.J.; Hudis, C.A. Obesity and Cancer Mechanisms: Tumor Microenvironment and Inflammation. J. Clin. Oncol. 2016, 34, 4270-4276. [CrossRef]

104. Mauvais-Jarvis, F.; Clegg, D.J.; Hevener, A.L. The Role of Estrogens in Control of Energy Balance and Glucose Homeostasis. Endocr. Rev. 2013, 34, 309-338. [CrossRef]

105. Duggan, C.; Irwin, M.L.; Xiao, L.; Henderson, K.D.; Smith, A.W.; Baumgartner, R.N.; Baumgartner, K.B.; Bernstein, L.; BallardBarbash, R.; McTiernan, A. Associations of insulin resistance and adiponectin with mortality in women with breast cancer. J. Clin. Oncol. 2011, 29, 32-39. [CrossRef]

106. Nam, S.; Park, S.; Park, H.S.; Kim, S.; Kim, J.Y.; Kim, S.I. Association Between Insulin Resistance and Luminal B Subtype Breast Cancer in Postmenopausal Women. Medicine 2016, 95, e2825. [CrossRef]

107. Lago, F.; Gómez, R.; Gómez-Reino, J.J.; Dieguez, C.; Gualillo, O. Adipokines as novel modulators of lipid metabolism. Trends Biochem. Sci. 2009, 34, 500-510. [CrossRef] 
108. Gilbert, C.A.; Slingerland, J.M. Cytokines, Obesity, and Cancer: New Insights on Mechanisms Linking Obesity to Cancer Risk and Progression. Annu. Rev. Med. 2013, 64, 45-57. [CrossRef]

109. Mohammadpour, H.; Pourfathollah, A.A.; Zarif, M.N.; Shahbazfar, A.A. Irradiation enhances susceptibility of tumor cells to the antitumor effects of TNF- $\alpha$ activated adipose derived mesenchymal stem cells in breast cancer model. Sci. Rep. 2016, 6, 28433. [CrossRef]

110. Li, J.; Han, X. Adipocytokines and breast cancer. Curr. Probl. Cancer 2018, 42, 208-214. [CrossRef]

111. Gu, L.; Cao, C.; Fu, J.; Li, Q.; Li, D.-H.; Chen, M.-Y. Serum adiponectin in breast cancer. A meta-analysis. Medicine 2018, 97 , e11433. [CrossRef]

112. Kojta, I.; Chacińska, M.; Błachnio-Zabielska, A. Obesity, Bioactive Lipids, and Adipose Tissue Inflammation in Insulin Resistance. Nutrients 2020, 12, 1305. [CrossRef]

113. Niland, S.; Riscanevo, A.X.; Eble, J.A. Matrix Metalloproteinases Shape the Tumor Microenvironment in Cancer Progression. Int. J. Mol. Sci. 2021, 23, 146. [CrossRef]

114. Vasiljeva, O.; Papazoglou, A.; Krüger, A.; Brodoefel, H.; Korovin, M.; Deussing, J.; Augustin, N.; Nielsen, B.S.; Almholt, K.; Bogyo, M.; et al. Tumor cell-derived and macrophage-derived cathepsin B promotes progression and lung metastasis of mammary cancer. Cancer Res. 2006, 66, 5242-5250. [CrossRef]

115. Gocheva, V.; Wang, H.W.; Gadea, B.B.; Shree, T.; Hunter, K.E.; Garfall, A.L.; Berman, T.; Joyce, J.A. IL-4 induces cathepsin protease activity in tumor-associated macrophages to promote cancer growth and invasion. Genes Dev. 2010, 24, 241-255. [CrossRef]

116. Özdemir, B.C.; Pentcheva-Hoang, T.; Carstens, J.L.; Zheng, X.; Wu, C.C.; Simpson, T.R.; Laklai, H.; Sugimoto, H.; Kahlert, C.; Novitskiy, S.V.; et al. Depletion of carcinoma-associated fibroblasts and fibrosis induces immunosuppression and accelerates pancreas cancer with reduced survival. Cancer Cell 2014, 25, 719-734. [CrossRef]

117. Arnold, S.A.; Rivera, L.B.; Miller, A.F.; Carbon, J.G.; Dineen, S.P.; Xie, Y.; Castrillon, D.H.; Sage, E.H.; Puolakkainen, P.; Bradshaw, A.D.; et al. Lack of host SPARC enhances vascular function and tumor spread in an orthotopic murine model of pancreatic carcinoma. Dis. Model. Mech. 2010, 3, 57-72. [CrossRef]

118. Lu, P.; Takai, K.; Weaver, V.M.; Werb, Z. Extracellular Matrix Degradation and Remodeling in Development and Disease. Cold Spring Harb. Perspect. Biol. 2011, 3, a005058. [CrossRef]

119. Kessenbrock, K.; Plaks, V.; Werb, Z. Matrix metalloproteinases: Regulators of the tumor microenvironment. Cell 2010, 141, 52-67. [CrossRef]

120. Imai, K.; Hiramatsu, A.; Fukushima, D.; Pierschbacher, M.D.; Okada, Y. Degradation of decorin by matrix metalloproteinases: Identification of the cleavage sites, kinetic analyses and transforming growth factor- $\beta 1$ release. Biochem. J. 1997, 322, 809-814. [CrossRef]

121. Kessenbrock, K.; Wang, C.-Y.; Werb, Z. Matrix metalloproteinases in stem cell regulation and cancer. Matrix Biol. 2015, 44-46, 184-190. [CrossRef]

122. Yang, L.; Pang, Y.; Moses, H.L. TGF- $\beta$ and immune cells: An important regulatory axis in the tumor microenvironment and progression. Trends Immunol. 2010, 31, 220-227. [CrossRef]

123. Deryugina, E.I.; Quigley, J.P. Matrix metalloproteinases and tumor metastasis. Cancer Metastasis Rev. 2006, 25, 9-34. [CrossRef]

124. Ghajar, C.M.; Bissell, M.J. Tumor Engineering: The Other Face of Tissue Engineering. Tissue Eng. Part A 2010, 16, $2153-2156$. [CrossRef]

125. Benton, G.; DeGray, G.; Kleinman, H.K.; George, J.; Arnaoutova, I. In Vitro Microtumors Provide a Physiologically Predictive Tool for Breast Cancer Therapeutic Screening. PLoS ONE 2015, 10, e0123312. [CrossRef]

126. Tan, T.-T.; Coussens, L.M. Humoral immunity, inflammation and cancer. Curr. Opin. Immunol. 2007, 19, 209-216. [CrossRef]

127. Gout, S.; Huot, J. Role of cancer microenvironment in metastasis: Focus on colon cancer. Cancer Microenviron. Off. J. Int. Cancer Microenviron. Soc. 2008, 1, 69-83. [CrossRef]

128. Jung, Y.; Kim, J.K.; Shiozawa, Y.; Wang, J.; Mishra, A.; Joseph, J.; Berry, J.E.; McGee, S.; Lee, E.; Sun, H.; et al. Recruitment of mesenchymal stem cells into prostate tumours promotes metastasis. Nat. Commun. 2013, 4, 1795. [CrossRef]

129. Orimo, A.; Gupta, P.B.; Sgroi, D.C.; Arenzana-Seisdedos, F.; Delaunay, T.; Naeem, R.; Carey, V.J.; Richardson, A.L.; Weinberg, R.A Stromal fibroblasts present in invasive human breast carcinomas promote tumor growth and angiogenesis through elevated SDF-1/CXCL12 secretion. Cell 2005, 121, 335-348. [CrossRef]

130. Xue, X.; Lu, Z.; Tang, D.; Yao, J.; An, Y.; Wu, J.; Li, Q.; Gao, W.; Xu, Z.; Qian, Z.; et al. Galectin-1 secreted by activated stellate cells in pancreatic ductal adenocarcinoma stroma promotes proliferation and invasion of pancreatic cancer cells: An in vitro study on the microenvironment of pancreatic ductal adenocarcinoma. Pancreas 2011, 40, 832-839. [CrossRef]

131. Saussez, S.; Decaestecker, C.; Cludts, S.; Ernoux, P.; Chevalier, D.; Smetana, K.J.; André, S.; Leroy, X.; Gabius, H.J. Adhesion/growth-regulatory tissue lectin galectin-1 in relation to angiogenesis/lymphocyte infiltration and prognostic relevance of stromal up-regulation in laryngeal carcinomas. Anticancer Res. 2009, 29, 59-65.

132. Fang, M.; Yuan, J.; Peng, C.; Li, Y. Collagen as a double-edged sword in tumor progression. Tumour Biol. J. Int. Soc. Oncodevelopmental Biol. Med. 2014, 35, 2871-2882. [CrossRef]

133. Provenzano, P.P.; Eliceiri, K.W.; Campbell, J.M.; Inman, D.R.; White, J.G.; Keely, P.J. Collagen reorganization at the tumor-stromal interface facilitates local invasion. BMC Med. 2006, 4, 38. [CrossRef]

134. Konstantinopoulos, P.; Karamouzis, M.; Papatsoris, A.; Papavassiliou, A. Matrix metalloproteinase inhibitors as anticancer agents. Int. J. Biochem. Cell Biol. 2008, 40, 1156-1168. [CrossRef] 
135. Cathcart, J.; Pulkoski-Gross, A.; Cao, J. Targeting matrix metalloproteinases in cancer: Bringing new life to old ideas. Genes Dis. 2015, 2, 26-34. [CrossRef]

136. Jiang, X.; Dutton, C.M.; Qi, W.N.; Block, J.A.; Brodt, P.; Durko, M.; Scully, S.P. Inhibition of MMP-1 expression by antisense RNA decreases invasiveness of human chondrosarcoma. J. Orthop. Res. 2003, 21, 1063-1070. [CrossRef]

137. Walker, C.; Mojares, E.; del Río Hernández, A. Role of Extracellular Matrix in Development and Cancer Progression. Int. J. Mol. Sci. 2018, 19, 3028. [CrossRef] [PubMed]

138. Morrissey, M.A.; Hagedorn, E.J.; Sherwood, D.R. Cell invasion through basement membrane: The netrin receptor DCC guides the way. Worm 2013, 2, e26169. [CrossRef] [PubMed]

139. Kelley, L.C.; Lohmer, L.L.; Hagedorn, E.J.; Sherwood, D.R. Traversing the basement membrane in vivo: A diversity of strategies. J. Cell Biol. 2014, 204, 291-302. [CrossRef] [PubMed]

140. Eterno, V.; Zambelli, A.; Pavesi, L.; Villani, L.; Zanini, V.; Petrolo, G.; Manera, S.; Tuscano, A.; Amato, A. Adipose-derived Mesenchymal Stem Cells (ASCs) may favour breast cancer recurrence via HGF/c-Met signaling. Oncotarget 2013, 5, 613-633. [CrossRef]

141. Rowan, B.G.; Gimble, J.M.; Sheng, M.; Anbalagan, M.; Jones, R.K.; Frazier, T.P.; Asher, M.; Lacayo, E.A.; Friedlander, P.L.; Kutner, R.; et al. Human adipose tissue-derived stromal/stem cells promote migration and early metastasis of triple negative breast cancer xenografts. PLoS ONE 2014, 9, e89595. [CrossRef]

142. Gehmert, S.; Gehmert, S.; Prantl, L.; Vykoukal, J.; Alt, E.; Song, Y.-H. Breast cancer cells attract the migration of adipose tissue-derived stem cells via the PDGF-BB/PDGFR- $\beta$ signaling pathway. Biochem. Biophys. Res. Commun. 2010, 398, 601-605. [CrossRef]

143. Amos, P.J.; Shang, H.; Bailey, A.M.; Taylor, A.; Katz, A.J.; Peirce, S.M. IFATS Collection: The Role of Human Adipose-Derived Stromal Cells in Inflammatory Microvascular Remodeling and Evidence of a Perivascular Phenotype. Stem Cells 2008, 26 2682-2690. [CrossRef]

144. Jotzu, C.; Alt, E.; Welte, G.; Li, J.; Hennessy, B.T.; Devarajan, E.; Krishnappa, S.; Pinilla, S.; Droll, L.; Song, Y.H. Adipose tissue derived stem cells differentiate into carcinoma-associated fibroblast-like cells under the influence of tumor derived factors. Cell. Oncol. 2011, 34, 55-67. [CrossRef]

145. Domingues, M.; Scientific, T.C. Role of ICAT (Inhibitor of $\beta$-Catenin and TCF4) in the Normal and Pathological Development of Melanocytes; René Descartes University: Paris, France, 2014.

146. Hiramatsu, R.; Matsuoka, T.; Kimura-Yoshida, C.; Han, S.W.; Mochida, K.; Adachi, T.; Takayama, S.; Matsuo, I. External mechanical cues trigger the establishment of the anterior-posterior axis in early mouse embryos. Dev. Cell 2013, 27, 131-144. [CrossRef]

147. Hagedorn, E.J.; Ziel, J.W.; Morrissey, M.A.; Linden, L.M.; Wang, Z.; Chi, Q.; Johnson, S.A.; Sherwood, D.R. The netrin receptor DCC focuses invadopodia-driven basement membrane transmigration in vivo. J. Cell Biol. 2013, 201, 903-913. [CrossRef]

148. Linder, S.; Wiesner, C.; Himmel, M. Degrading Devices: Invadosomes in Proteolytic Cell Invasion. Annu. Rev. Cell Dev. Biol. 2011, 27, 185-211. [CrossRef]

149. Schoumacher, M.; Goldman, R.D.; Louvard, D.; Vignjevic, D.M. Actin, microtubules, and vimentin intermediate filaments cooperate for elongation of invadopodia. J. Cell Biol. 2010, 189, 541-556. [CrossRef]

150. Ihara, S.; Hagedorn, E.J.; Morrissey, M.A.; Chi, Q.; Motegi, F.; Kramer, J.M.; Sherwood, D.R. Basement membrane sliding and targeted adhesion remodels tissue boundaries during uterine-vulval attachment in Caenorhabditis elegans. Nat. Cell Biol. 2011, 13, 641-651. [CrossRef]

151. Valastyan, S.; Weinberg, R.A. Tumor Metastasis: Molecular Insights and Evolving Paradigms. Cell 2011, 147, 275-292. [CrossRef]

152. Moustakas, A.; de Herreros, A.G. Epithelial-mesenchymal transition in cancer. Mol. Oncol. 2017, 11, 715-717. [CrossRef]

153. Roche, J. The Epithelial-to-Mesenchymal Transition in Cancer. Cancers 2018, 10, 52. [CrossRef]

154. Frixen, U.H.; Behrens, J.; Sachs, M.; Eberle, G.; Voss, B.; Warda, A.; Löchner, D.; Birchmeier, W. E-cadherin-mediated cell-cell adhesion prevents invasiveness of human carcinoma cells. J. Cell Biol. 1991, 113, 173-185. [CrossRef]

155. McAllister, S.S.; Weinberg, R.A. The tumour-induced systemic environment as a critical regulator of cancer progression and metastasis. Nat. Cell Biol. 2014, 16, 717-727. [CrossRef]

156. Scully, O.J.; Bay, B.H.; Yip, G.; Yu, Y. Breast cancer metastasis. Cancer Genom. Proteom. 2012, 9, 311-320.

157. Fidler, I.J.; Kripke, M.L. The challenge of targeting metastasis. Cancer Metastasis Rev. 2015, 34, 635-641. [CrossRef]

158. Kitamura, T.; Qian, B.-Z.; Pollard, J.W. Immune cell promotion of metastasis. Nat. Rev. Immunol. 2015, 15, 73-86. [CrossRef]

159. Grivennikov, S.I.; Greten, F.R.; Karin, M. Immunity, inflammation, and cancer. Cell 2010, 140, 883-899. [CrossRef]

160. Trinchieri, G. Cancer and Inflammation: An Old Intuition with Rapidly Evolving New Concepts. Annu. Rev. Immunol. 2012, 30, 677-706. [CrossRef]

161. Zamarron, B.; Chen, W. Dual Roles of Immune Cells and Their Factors in Cancer Development and Progression. Int. J. Biol. Sci. 2011, 7, 651-658. [CrossRef]

162. Shalapour, S.; Karin, M. Immunity, inflammation, and cancer: An eternal fight between good and evil. J. Clin. Investig. 2015, 125, 3347-3355. [CrossRef] [PubMed]

163. Sica, A. Role of tumour-associated macrophages in cancer-related inflammation. Exp. Oncol. 2010, 32, 153-158. [PubMed] 
164. Fu, X.-T.; Dai, Z.; Song, K.; Zhang, Z.J.; Zhou, Z.J.; Zhou, S.L.; Zhao, Y.M.; Xiao, Y.S.; Sun, Q.M.; Ding, Z.B.; et al. Macrophagesecreted IL-8 induces epithelial-mesenchymal transition in hepatocellular carcinoma cells by activating the JAK2/STAT3/Snail pathway. Int. J. Oncol. 2015, 46, 587-596. [CrossRef]

165. Wu, Y.; Deng, J.; Rychahou, P.; Qiu, S.; Evers, B.M.; Zhou, B.P. Stabilization of Snail by NF-кB Is Required for Inflammation-Induced Cell Migration and Invasion. Cancer Cell 2009, 15, 416-428. [CrossRef] [PubMed]

166. Kawata, M.; Koinuma, D.; Ogami, T.; Umezawa, K.; Iwata, C.; Watabe, T.; Miyazono, K. TGF- $\beta$-induced epithelial-mesenchymal transition of A549 lung adenocarcinoma cells is enhanced by pro-inflammatory cytokines derived from RAW 264.7 macrophage cells. J. Biochem. 2012, 151, 205-216. [CrossRef] [PubMed]

167. Pinilla, S.; Alt, E.; Abdul Khalek, F.J.; Jotzu, C.; Muehlberg, F.; Beckmann, C.; Song, Y.H. Tissue resident stem cells produce CCL5 under the influence of cancer cells and thereby promote breast cancer cell invasion. Cancer Lett. 2009, 284, 80-85. [CrossRef]

168. Park, J.; Morley, T.S.; Kim, M.; Clegg, D.J.; Scherer, P.E. Obesity and cancer-Mechanisms underlying tumour progression and recurrence. Nat. Rev. Endocrinol. 2014, 10, 455-465. [CrossRef]

169. Nathan, C. Metchnikoff's Legacy in 2008. Nat. Immunol. 2008, 9, 695-698. [CrossRef]

170. Gordon, S. Alternative activation of macrophages. Nat. Rev. Immunol. 2003, 3, 23-35. [CrossRef]

171. Russell, D.G.; Cardona, P.-J.; Kim, M.-J.; Allain, S.; Altare, F. Foamy macrophages and the progression of the human tuberculosis granuloma. Nat. Immunol. 2009, 10, 943-948. [CrossRef]

172. Serhan, C.N.; Savill, J. Resolution of inflammation: The beginning programs the end. Nat. Immunol. 2005, 6, 1191-1197. [CrossRef]

173. Mosser, D.M.; Edwards, J.P. Exploring the full spectrum of macrophage activation. Nat. Rev. Immunol. 2008, 8, 958-969. [CrossRef]

174. Hotamisligil, G.S.; Erbay, E. Nutrient sensing and inflammation in metabolic diseases. Nat. Rev. Immunol. 2008, 8, 923-934. [CrossRef]

175. Lumeng, C.N.; Saltiel, A. Inflammatory links between obesity and metabolic disease. J. Clin. Investig. 2011, 121, $2111-2117$. [CrossRef]

176. Jiang, M.H.; Lim, J.E.; Chi, G.F.; Ahn, W.; Zhang, M.; Chung, E.; Son, Y. Substance P reduces apoptotic cell death possibly by modulating the immune response at the early stage after spinal cord injury. Neuroreport 2013, 24, 846-851. [CrossRef]

177. Leek, R.; Harris, A.; Lewis, C. Cytokine networks in solid human tumors: Regulation of angiogenesis. J. Leukoc. Biol. 1994, 56, 423-435. [CrossRef]

178. Kelly, P.M.; Davison, R.S.; Bliss, E.; McGee, J.O. Macrophages in human breast disease: A quantitative immunohistochemical study. Br. J. Cancer 1988, 57, 174-177. [CrossRef]

179. Murdoch, C.; Muthana, M.; Coffelt, S.; Lewis, C.E. The role of myeloid cells in the promotion of tumour angiogenesis. Nat. Cancer 2008, 8, 618-631. [CrossRef]

180. Lewis, C.E.; Pollard, J.W. Distinct Role of Macrophages in Different Tumor Microenvironments. Cancer Res. 2006, 66, 605-612. [CrossRef]

181. Bingle, L.; Brown, N.; Lewis, C.E. The role of tumour-associated macrophages in tumour progression: Implications for new anticancer therapies. J. Pathol. 2002, 196, 254-265. [CrossRef]

182. Biswas, S.K.; Gangi, L.; Paul, S.; Schioppa, T.; Saccani, A.; Sironi, M.; Bottazzi, B.; Doni, A.; Vincenzo, B.; Pasqualini, F.; et al. A distinct and unique transcriptional program expressed by tumor-associated macrophages (defective NF-kappaB and enhanced IRF-3/STAT1 activation). Blood 2006, 107, 2112-2122. [CrossRef]

183. Saccani, A.; Schioppa, T.; Porta, C.; Biswas, S.K.; Nebuloni, M.; Vago, L.; Bottazzi, B.; Colombo, M.P.; Mantovani, A.; Sica, A. p50 nuclear factor-kappaB overexpression in tumor-associated macrophages inhibits M1 inflammatory responses and antitumor resistance. Cancer Res. 2006, 66, 11432-11440. [CrossRef] [PubMed]

184. Fujimoto, H.; Sangai, T.; Ishii, G.; Ikehara, A.; Nagashima, T.; Miyazaki, M.; Ochiai, A. Stromal MCP-1 in mammary tumors induces tumor-associated macrophage infiltration and contributes to tumor progression. Int. J. Cancer 2009, 125, 1276-1284. [CrossRef] [PubMed]

185. Gordon, S.; Taylor, P. Monocyte and macrophage heterogeneity. Nat. Rev. Immunol. 2005, 5, 953-964. [CrossRef] [PubMed]

186. Ueno, T.; Toi, M.; Saji, H.; Muta, M.; Bando, H.; Kuroi, K.; Koike, M.; Inadera, H.; Matsushima, K. Significance of macrophage chemoattractant protein-1 in macrophage recruitment, angiogenesis, and survival in human breast cancer. Clin. Cancer Res. Off. J. Am. Assoc. Cancer Res. 2000, 6, 3282-3289.

187. Lin, E.Y.; Nguyen, A.V.; Russell, R.G.; Pollard, J.W. Colony-Stimulating Factor 1 Promotes Progression of Mammary Tumors to Malignancy. J. Exp. Med. 2001, 193, 727-740. [CrossRef]

188. Lewis, J.S.; Landers, R.J.; Underwood, J.C.; Harris, A.L.; Lewis, C.E. Expression of vascular endothelial growth factor by macrophages is up-regulated in poorly vascularized areas of breast carcinomas. J. Pathol. 2000, 192, 150-158. [CrossRef]

189. Mao, Y.; Poschke, I.; Kiessling, R. Tumour-induced immune suppression: Role of inflammatory mediators released by myelomonocytic cells. J. Intern. Med. 2014, 276, 154-170. [CrossRef]

190. Gorelik, E.; Wiltrout, R.H.; Brunda, M.J.; Holden, H.T.; Herberman, R.B. Augmentation of metastasis formation by thioglycollateelicited macrophages. Int. J. Cancer 1982, 29, 575-581. [CrossRef]

191. Coffelt, S.B.; Hughes, R.; Lewis, C.E. Tumor-associated macrophages: Effectors of angiogenesis and tumor progression. Biochim. Biophys. Acta 2009, 1796, 11-18. [CrossRef]

192. Wyckoff, J.B.; Wang, Y.; Lin, E.Y.; Li, J.F.; Goswami, S.; Stanley, E.R.; Segall, J.E.; Pollard, J.W.; Condeelis, J. Direct visualization of macrophage-assisted tumor cell intravasation in mammary tumors. Cancer Res. 2007, 67, 2649-2656. [CrossRef] [PubMed] 
193. Guruvayoorappan, C. Tumor Versus Tumor-Associated Macrophages: How Hot is the Link? Integr. Cancer Ther. 2008, 7, 90-95. [CrossRef] [PubMed]

194. Grimshaw, M.J.; Hagemann, T.; Ayhan, A.; Gillett, C.E.; Binder, C.; Balkwill, F. A Role for Endothelin-2 and Its Receptors in Breast Tumor Cell Invasion. Cancer Res. 2004, 64, 2461-2468. [CrossRef]

195. Hagemann, T.; Robinson, S.C.; Schulz, M.; Trümper, L.; Balkwill, F.; Binder, C. Enhanced invasiveness of breast cancer cell lines upon co-cultivation with macrophages is due to TNF- dependent up-regulation of matrix metalloproteases. Carcinogenesis 2004, 25, 1543-1549. [CrossRef]

196. Kawasaki, E.S.; Ladner, M.B. Molecular biology of macrophage colony-stimulating factor. Immunol. Ser. 1990, 49, 155-176. [PubMed]

197. Dorsch, M.; Hock, H.; Kunzendorf, U.; Diamantstein, T.; Blankenstein, T. Macrophage colony-stimulating factor gene transfer into tumor cells induces macrophage infiltration but not tumor suppression. Eur. J. Immunol. 1993, 23, 186-190. [CrossRef]

198. Tang, R.P.; Kacinski, B.; Validire, P.; Beuvon, F.; Sastre, X.; Benoit, P.; dela Rochefordière, A.; Mosseri, V.; Pouillart, P.; Scholl, S Oncogene amplification correlates with dense lymphocyte infiltration in human breast cancers: A role for hematopoietic growth factor release by tumor cells? J. Cell. Biochem. 1990, 44, 189-198. [CrossRef]

199. Mazzucchelli, L.; Loetscher, P.; Kappeler, A.; Uguccioni, M.; Baggiolini, M.; Laissue, J.A.; Mueller, C. Monocyte chemoattractant protein-1 gene expression in prostatic hyperplasia and prostate adenocarcinoma. Am. J. Pathol. 1996, 149, 501-509.

200. Siveen, K.S.; Kuttan, G. Role of macrophages in tumour progression. Immunol. Lett. 2009, 123, 97-102. [CrossRef]

201. O'Sullivan, T.; Saddawi-Konefka, R.; Vermi, W.; Koebel, C.M.; Arthur, C.; White, J.M.; Uppaluri, R.; Andrews, D.M.; Ngiow, S.F.; Teng, M.W.L.; et al. Cancer immunoediting by the innate immune system in the absence of adaptive immunity. J. Exp. Med. 2012, 209, 1869-1882. [CrossRef]

202. Bronkhorst, I.H.G.; Ly, L.V.; Jordanova, E.S.; Vrolijk, J.; Versluis, M.; Luyten, G.P.M.; Jager, M.J. Detection of M2-macrophages in uveal melanoma and relation with survival. Investig. Ophthalmol. Vis. Sci. 2011, 52, 643-650. [CrossRef]

203. Ly, L.V.; Baghat, A.; Versluis, M.; Jordanova, E.S.; Luyten, G.P.M.; van Rooijen, N.; van Hall, T.; van der Velden, P.A.; Jager, M.J. In aged mice, outgrowth of intraocular melanoma depends on proangiogenic M2-type macrophages. J. Immunol. 2010, 185, 3481-3488. [CrossRef] [PubMed]

204. Tao, M.; Liu, L.; Shen, M.; Zhi, Q.; Gong, F.R.; Zhou, B.P.; Wu, Y.; Liu, H.; Chen, K.; Shen, B.; et al. Inflammatory stimuli promote growth and invasion of pancreatic cancer cells through NF-kB pathway dependent repression of PP2Ac. Cell Cycle 2016, 15, 381-393. [CrossRef] [PubMed]

205. Dunn, G.P.; Old, L.J.; Schreiber, R.D. The Three Es of Cancer Immunoediting. Annu. Rev. Immunol. 2004, 22, 329-360. [CrossRef]

206. Egeblad, M.; Nakasone, E.S.; Werb, Z. Tumors as Organs: Complex Tissues that Interface with the Entire Organism. Dev. Cell 2010, 18, 884-901. [CrossRef] [PubMed]

207. Mantovani, A. Molecular pathways linking inflammation and cancer. Curr. Mol. Med. 2010, 10, 369-373. [CrossRef]

208. Ricciardi, M.; Zanotto, M.; Malpeli, G.; Bassi, G.; Perbellini, O.; Chilosi, M.; Bifari, F.; Krampera, M. Epithelial-to-mesenchymal transition (EMT) induced by inflammatory priming elicits mesenchymal stromal cell-like immune-modulatory properties in cancer cells. Br. J. Cancer 2015, 112, 1067-1075. [CrossRef]

209. Allavena, P.; Sica, A.; Garlanda, C.; Mantovani, A. The Yin-Yang of tumor-associated macrophages in neoplastic progression and immune surveillance. Immunol. Rev. 2008, 222, 155-161. [CrossRef]

210. DeNardo, D.G.; Barreto, J.B.; Andreu, P.; Vasquez, L.; Tawfik, D.; Kolhatkar, N.; Coussens, L.M. CD4(+) T cells regulate pulmonary metastasis of mammary carcinomas by enhancing protumor properties of macrophages. Cancer Cell 2009, 16, 91-102. [CrossRef]

211. Obiri, N.I.; Debinski, W.; Leonard, W.J.; Puri, R.K. Receptor for interleukin 13. Interaction with interleukin 4 by a mechanism that does not involve the common gamma chain shared by receptors for interleukins 2, 4, 7, 9, and 15. J. Biol. Chem. 1995, 270, 8797-8804. [CrossRef]

212. Mantovani, A.; Marchesi, F.; Malesci, A.; Laghi, L.; Allavena, P. Tumour-associated macrophages as treatment targets in oncology. Nat. Rev. Clin. Oncol. 2017, 14, 399-416. [CrossRef]

213. Miyake, M.; Hori, S.; Morizawa, Y.; Tatsumi, Y.; Nakai, Y.; Anai, S.; Torimoto, K.; Aoki, K.; Tanaka, N.; Shimada, K.; et al. CXCL1-Mediated Interaction of Cancer Cells with Tumor-Associated Macrophages and Cancer-Associated Fibroblasts Promotes Tumor Progression in Human Bladder Cancer. Neoplasia 2016, 18, 636-646. [CrossRef] [PubMed]

214. Shigdar, S.; Li, Y.; Bhattacharya, S.; O'Connor, M.; Pu, C.; Lin, J.; Wang, T.; Xiang, D.; Kong, L.; Wei, M.Q.; et al. Inflammation and cancer stem cells. Cancer Lett. 2014, 345, 271-278. [CrossRef] [PubMed]

215. Shi, C.; Pamer, E.G. Monocyte recruitment during infection and inflammation. Nat. Rev. Immunol. 2011, 11, 762-774. [CrossRef] [PubMed]

216. Davis, M.J.; Tsang, T.M.; Qiu, Y.; Dayrit, J.K.; Freij, J.B.; Huffnagle, G.B.; Olszewski, M.A. Macrophage M1/M2 polarization dynamically adapts to changes in cytokine microenvironments in Cryptococcus neoformans infection. MBio 2013, 4, e00264-13. [CrossRef]

217. Mantovani, A.; Sozzani, S.; Locati, M.; Allavena, P.; Sica, A. Macrophage polarization: Tumor-associated macrophages as a paradigm for polarized M2 mononuclear phagocytes. Trends Immunol. 2002, 23, 549-555. [CrossRef]

218. Kurte, M.; López, M.; Aguirre, A.; Escobar, A.; Aguillón, J.; Charo, J.; Larsen, C.; Kiessling, R.; Salazar Onfray, F. A Synthetic Peptide Homologous to Functional Domain of Human IL-10 Down-Regulates Expression of MHC Class I and Transporter Associated with Antigen Processing 1/2 in Human Melanoma Cells. J. Immunol. 2004, 173, 1731-1737. [CrossRef] 
219. Auffray, C.; Sieweke, M.H.; Geissmann, F. Blood Monocytes: Development, Heterogeneity, and Relationship with Dendritic Cells. Annu. Rev. Immunol. 2009, 27, 669-692. [CrossRef]

220. De Palma, M.; Lewis, C.E. Macrophage Regulation of Tumor Responses to Anticancer Therapies. Cancer Cell 2013, $23,277-286$. [CrossRef]

221. Biswas, S.K.; Mantovani, A. Macrophage plasticity and interaction with lymphocyte subsets: Cancer as a paradigm. Nat. Immunol. 2010, 11, 889-896. [CrossRef]

222. Pollard, J.W. Tumour-educated macrophages promote tumour progression and metastasis. Nat. Rev. Cancer 2004, 4, 71-78. [CrossRef] [PubMed]

223. Yoshimura, A. Signal transduction of inflammatory cytokines and tumor development. Cancer Sci. 2006, 97, 439-447. [CrossRef] [PubMed]

224. Loges, S.; Schmidt, T.; Tjwa, M.; van Geyte, K.; Lievens, D.; Lutgens, E.; Vanhoutte, D.; Borgel, D.; Plaisance, S.; Hoylaerts, M.; et al. Malignant cells fuel tumor growth by educating infiltrating leukocytes to produce the mitogen Gas6. Blood 2010, 115, $2264-2273$. [CrossRef]

225. Mantovani, A. From phagocyte diversity and activation to probiotics: Back to Metchnikoff. Eur. J. Immunol. 2008, 38, 3269-3273. [CrossRef] [PubMed]

226. Riabov, V.; Gudima, A.; Wang, N.; Mickley, A.; Orekhov, A.; Kzhyshkowska, J. Role of tumor associated macrophages in tumor angiogenesis and lymphangiogenesis. Front. Physiol. 2014, 5, 75. [CrossRef]

227. Winston, B.W.; Krein, P.M.; Mowat, C.; Huang, Y. Cytokine-induced macrophage differentiation: A tale of 2 genes. Clin. Investig. Med. 1999, 22, 236-255.

228. Hagemann, T.; Lawrence, T.; McNeish, I.; Charles, K.A.; Kulbe, H.; Thompson, R.G.; Robinson, S.C.; Balkwill, F.R. Re-educating tumor-associated macrophages by targeting NF-kappaB. J. Exp. Med. 2008, 205, 1261-1268. [CrossRef]

229. Torroella-Kouri, M.; Silvera, R.; Rodriguez, D.; Caso, R.; Shatry, A.; Opiela, S.; Ilkovitch, D.; Schwendener, R.A.; IragavarapuCharyulu, V.; Cardentey, Y.; et al. Identification of a subpopulation of macrophages in mammary tumor-bearing mice that are neither M1 nor M2 and are less differentiated. Cancer Res. 2009, 69, 4800-4809. [CrossRef]

230. Sierra, J.R.; Corso, S.; Caione, L.; Cepero, V.; Conrotto, P.; Cignetti, A.; Piacibello, W.; Kumanogoh, A.; Kikutani, H.; Comoglio, P.M.; et al. Tumor angiogenesis and progression are enhanced by Sema4D produced by tumor-associated macrophages. J. Exp. Med. 2008, 205, 1673-1685. [CrossRef]

231. Mantovani, A.; Allavena, P.; Sica, A.; Balkwill, F. Cancer-related inflammation. Nature 2008, 454, 436-444. [CrossRef]

232. Gaudet, M.M.; Press, M.F.; Haile, R.W.; Lynch, C.F.; Glaser, S.L.; Schildkraut, J.; Gammon, M.D.; Douglas, T.W.; Bernstein, J.L. Risk factors by molecular subtypes of breast cancer across a population-based study of women 56 years or younger. Breast Cancer Res. Treat. 2011, 130, 587-597. [CrossRef] [PubMed]

233. Larsson, S.C.; Mantzoros, C.S.; Wolk, A. Diabetes mellitus and risk of breast cancer: A meta-analysis. Int. J. Cancer 2007, 121, 856-862. [CrossRef] [PubMed]

234. Benoit, M.; Desnues, B.; Mege, J.-L. Macrophage Polarization in Bacterial Infections. J. Immunol. 2008, 181, 3733-3739. [CrossRef]

235. Lamagna, C.; Aurrand-Lions, M.; Imhof, B.A. Dual role of macrophages in tumor growth and angiogenesis. J. Leukoc. Biol. 2006, 80, 705-713. [CrossRef] [PubMed]

236. Mosser, D.M. The many faces of macrophage activation. J. Leukoc. Biol. 2003, 73, 209-212. [CrossRef] [PubMed]

237. Sica, A.; Mantovani, A. Macrophage plasticity and polarization: In vivo veritas. J. Clin. Investig. 2012, 122, 787-795. [CrossRef]

238. Verreck, F.A.W.; De Boer, T.; Langenberg, D.M.L.; Hoeve, M.A.; Kramer, M.; Vaisberg, E.; Kastelein, R.; Kolk, A.; De Waal-Malefyt, R.; Ottenhoff, T.H.M. Human IL-23-producing type 1 macrophages promote but IL-10-producing type 2 macrophages subvert immunity to (myco)bacteria. Proc. Natl. Acad. Sci. USA 2004, 101, 4560-4565. [CrossRef]

239. Movahedi, K.; Laoui, D.; Gysemans, C.; Baeten, M.; Stangé, G.; Van den Bossche, J.; Mack, M.; Pipeleers, D.; In’t Veld, P.; De Baetselier, P.; et al. Different tumor microenvironments contain functionally distinct subsets of macrophages derived from Ly6C(high) monocytes. Cancer Res. 2010, 70, 5728-5739. [CrossRef]

240. Bancroft, G.J.; Schreiber, R.D.; Unanue, E.R. Natural Immunity: A T-Cell-Independent Pathway of Macrophage Activation, Defined in the scid Mouse. Immunol. Rev. 1991, 124, 5-24. [CrossRef]

241. Italiani, P.; Boraschi, D.; Italiani, P.; Boraschi, D. From Monocytes to M1/M2 Macrophages: Phenotypical vs. Functional Differentiation. Front. Immunol. 2014, 5, 514. [CrossRef]

242. Ruffell, B.; Coussens, L.M. Macrophages and Therapeutic Resistance in Cancer. Cancer Cell 2015, 27, 462-472. [CrossRef] [PubMed]

243. Pollard, J.W. Trophic macrophages in development and disease. Nat. Rev. Immunol. 2009, 9, 259-270. [CrossRef] [PubMed]

244. Ben-Baruch, A. Inflammation-associated immune suppression in cancer: The roles played by cytokines, chemokines and additional mediators. Semin. Cancer Biol. 2006, 16, 38-52. [CrossRef] [PubMed]

245. Martinez, F.O.; Helming, L.; Gordon, S. Alternative Activation of Macrophages: An Immunologic Functional Perspective. Annu. Rev. Immunol. 2009, 27, 451-483. [CrossRef] [PubMed]

246. Laoui, D.; Movahedi, K.; Van Overmeire, E.; Van den Bossche, J.; Schouppe, E.; Mommer, C.; Nikolaou, A.; Morias, Y.; De Baetselier, P.; Van Ginderachter, J.A. Tumor-associated macrophages in breast cancer: Distinct subsets, distinct functions. Int. J. Dev. Biol. 2011, 55, 861-867. [CrossRef]

247. Ruffell, B.; Affara, N.I.; Coussens, L.M. Differential macrophage programming in the tumor microenvironment. Trends Immunol. 2012, 33, 119-126. [CrossRef] 
248. Singh, S.; Mehta, N.; Lilan, J.; Budhthoki, M.B.; Chao, F.; Yong, L. Initiative action of tumor-associated macrophage during tumor metastasis. Biochim. Open 2017, 4, 8-18. [CrossRef]

249. Komohara, Y.; Jinushi, M.; Takeya, M. Clinical significance of macrophage heterogeneity in human malignant tumors. Cancer Sci. 2013, 105, 1-8. [CrossRef]

250. Ross, S.E.; Erickson, R.L.; Gerin, I.; DeRose, P.M.; Bajnok, L.; Longo, K.A.; Misek, D.E.; Kuick, R.; Hanash, S.M.; Atkins, K.B.; et al. Microarray analyses during adipogenesis: Understanding the effects of Wnt signaling on adipogenesis and the roles of liver $\mathrm{X}$ receptor alpha in adipocyte metabolism. Mol. Cell. Biol. 2002, 22, 5989-5999. [CrossRef]

251. Gordon, $\mathrm{S}$. The role of the macrophage in immune regulation. Res. Immunol. 1998, 149, 685-688. [CrossRef]

252. Pandey, M.; Tuncman, G.; Hotamisligil, G.S.; Samad, F. Divergent Roles for p55 and p75 TNF- $\alpha$ Receptors in the Induction of Plasminogen Activator Inhibitor-1. Am. J. Pathol. 2003, 162, 933-941. [CrossRef]

253. Ouchi, N.; Parker, J.L.; Lugus, J.J.; Walsh, K. Adipokines in inflammation and metabolic disease. Nat. Rev. Immunol. 2011, 11, 85-97. [CrossRef]

254. Kintscher, U.; Hartge, M.; Hess, K.; Foryst-Ludwig, A.; Clemenz, M.; Wabitsch, M.; Fischer-Posovszky, P.; Barth, T.F.E.; Dragun, D.; Skurk, T.; et al. T-lymphocyte infiltration in visceral adipose tissue: A primary event in adipose tissue inflammation and the development of obesity-mediated insulin resistance. Arterioscler. Thromb. Vasc. Biol. 2008, 28, 1304-1310. [CrossRef] [PubMed]

255. Wu, H.; Ghosh, S.; Perrard, X.D.; Feng, L.; Garcia, G.E.; Perrard, J.L.; Sweeney, J.F.; Peterson, L.E.; Chan, L.; Smith, C.W.; et al. T-cell accumulation and regulated on activation, normal $\mathrm{T}$ cell expressed and secreted upregulation in adipose tissue in obesity. Circulation 2007, 115, 1029-1038. [CrossRef] [PubMed]

256. Yang, H.; Youm, Y.H.; Vandanmagsar, B.; Ravussin, A.; Gimble, J.M.; Greenway, F.; Stephens, J.M.; Mynatt, R.L.; Dixit, V.D. Obesity increases the production of proinflammatory mediators from adipose tissue T cells and compromises TCR repertoire diversity: Implications for systemic inflammation and insulin resistance. J. Immunol. 2010, 185, 1836-1845. [CrossRef] [PubMed]

257. Feuerer, M.; Herrero, L.; Cipolletta, D.; Naaz, A.; Wong, J.; Nayer, A.; Lee, J.; Goldfine, A.B.; Benoist, C.; Shoelson, S.; et al. Lean, but not obese, fat is enriched for a unique population of regulatory T cells that affect metabolic parameters. Nat. Med. 2009, 15, 930-939. [CrossRef]

258. De Palma, M.; Murdoch, C.; Venneri, M.A.; Naldini, L.; Lewis, C.E. Tie2-expressing monocytes: Regulation of tumor angiogenesis and therapeutic implications. Trends Immunol. 2007, 28, 519-524. [CrossRef]

259. Mantovani, A.; Sica, A.; Sozzani, S.; Allavena, P.; Vecchi, A.; Locati, M. The chemokine system in diverse forms of macrophage activation and polarization. Trends Immunol. 2004, 25, 677-686. [CrossRef]

260. Gensel, J.C.; Zhang, B. Macrophage activation and its role in repair and pathology after spinal cord injury. Brain Res. 2015, 1619, 1-11. [CrossRef]

261. Obeid, E.; Nanda, R.; Fu, Y.-X.; Olopade, O.I. The role of tumor-associated macrophages in breast cancer progression. Int. J. Oncol. 2013, 43, 5-12. [CrossRef]

262. Smith, T.D.; Tse, M.J.; Read, E.L.; Liu, W.F. Regulation of macrophage polarization and plasticity by complex activation signals. Integr. Biol. (Camb). 2016, 8, 946-955. [CrossRef] [PubMed]

263. Murray, P.J.; Allen, J.E.; Biswas, S.K.; Fisher, E.A.; Gilroy, D.W.; Goerdt, S.; Gordon, S.; Hamilton, J.A.; Ivashkiv, L.B.; Lawrence, T.; et al. Perspective Macrophage Activation and Polarization: Nomenclature and Experimental Guidelines. Immunity 2014, 41, 14-20. [CrossRef] [PubMed]

264. Kusmartsev, S.; Gabrilovich, D.I. STAT1 Signaling Regulates Tumor-Associated Macrophage-Mediated T Cell Deletion. J. Immunol. 2005, 174, 4880-4891. [CrossRef]

265. Zhang, M.; He, Y.; Sun, X.; Li, Q.; Wang, W.; Zhao, A.; Di, W. A high M1/M2 ratio of tumor-associated macrophages is associated with extended survival in ovarian cancer patients. J. Ovarian Res. 2014, 7, 19. [CrossRef] [PubMed]

266. Henze, A.-T.; Mazzone, M. The impact of hypoxia on tumor-associated macrophages. J. Clin. Investig. 2016, 126, 3672-3679. [CrossRef] [PubMed]

267. Mantovani, A.; Biswas, S.K.; Galdiero, M.R.; Sica, A.; Locati, M. Macrophage plasticity and polarization in tissue repair and remodelling. J. Pathol. 2012, 229, 176-185. [CrossRef] [PubMed]

268. Tsutsui, S.; Yasuda, K.; Suzuki, K.; Tahara, K.; Higashi, H.; Era, S. Macrophage infiltration and its prognostic implications in breast cancer: The relationship with VEGF expression and microvessel density. Oncol. Rep. 2005, 14, 425-431. [CrossRef]

269. Grivennikov, S.I.; Wang, K.; Mucida, D.; Stewart, C.A.; Schnabl, B.; Jauch, D.; Taniguchi, K.; Yu, G.Y.; Osterreicher, C.H.; Hung, K.E.; et al. Adenoma-linked barrier defects and microbial products drive IL-23/IL-17-mediated tumour growth. Nature 2012, 491, 254-258. [CrossRef]

270. Kong, L.; Zhou, Y.; Bu, H.; Lv, T.; Shi, Y.; Yang, J. Deletion of interleukin-6 in monocytes/macrophages suppresses the initiation of hepatocellular carcinoma in mice. J. Exp. Clin. Cancer Res. 2016, 35, 131. [CrossRef] [PubMed]

271. Dineen, S.P.; Lynn, K.D.; Holloway, S.E.; Miller, A.F.; Sullivan, J.P.; Shames, D.S.; Beck, A.W.; Barnett, C.C.; Fleming, J.B.; Brekken, R.A. Vascular endothelial growth factor receptor 2 mediates macrophage infiltration into orthotopic pancreatic tumors in mice. Cancer Res. 2008, 68, 4340-4346. [CrossRef]

272. Green, J.R.; Guenther, A. The backbone of progress-Preclinical studies and innovations with zoledronic acid. Crit. Rev. Oncol. 2011, 77, S3-S12. [CrossRef] 
273. Gnant, M.; Mlineritsch, B.; Schippinger, W.; Luschin-Ebengreuth, G.; Pöstlberger, S.; Menzel, C.; Jakesz, R.; Seifert, M.; Hubalek, M.; Bjelic-Radisic, V.; et al. Endocrine therapy plus zoledronic acid in premenopausal breast cancer. N. Engl. J. Med. 2009, 360, 679-691. [CrossRef]

274. Bak, S.P.; Alonso, A.; Turk, M.J.; Berwin, B. Murine ovarian cancer vascular leukocytes require arginase-1 activity for T cell suppression. Mol. Immunol. 2008, 46, 258-268. [CrossRef] [PubMed]

275. Schutyser, E.; Struyf, S.; Proost, P.; Opdenakker, G.; Laureys, G.; Verhasselt, B.; Peperstraete, L.; Van de Putte, I.; Saccani, A.; Allavena, P.; et al. Identification of biologically active chemokine isoforms from ascitic fluid and elevated levels of CCL18/pulmonary and activation-regulated chemokine in ovarian carcinoma. J. Biol. Chem. 2002, 277, 24584-24593. [CrossRef] [PubMed]

276. Allavena, P.; Sica, A.; Solinas, G.; Porta, C.; Mantovani, A. The inflammatory micro-environment in tumor progression: The role of tumor-associated macrophages. Crit. Rev. Oncol. Hematol. 2008, 66, 1-9. [CrossRef]

277. Ito, M.; Minamiya, Y.; Kawai, H.; Saito, S.; Saito, H.; Nakagawa, T.; Imai, K.; Hirokawa, M.; Ogawa, J.I. Tumor-Derived TGF $\beta-1$ Induces Dendritic Cell Apoptosis in the Sentinel Lymph Node. J. Immunol. 2006, 176, 5637-5643. [CrossRef]

278. Weber, F.; Byrne, S.N.; Le, S.; Brown, D.A.; Breit, S.N.; Scolyer, R.A.; Halliday, G.M. Transforming growth factor-beta1 immobilises dendritic cells within skin tumours and facilitates tumour escape from the immune system. Cancer Immunol. Immunother. 2005, 54, 898-906. [CrossRef]

279. Maeda, H.; Shiraishi, A. TGF-beta contributes to the shift toward Th2-type responses through direct and IL-10-mediated pathways in tumor-bearing mice. J. Immunol. 1996, 156, 73-78.

280. Castriconi, R.; Cantoni, C.; Della Chiesa, M.; Vitale, M.; Marcenaro, E.; Conte, R.; Biassoni, R.; Bottino, C.; Moretta, L.; Moretta Alessandro, G.M. Transforming growth factor beta 1 inhibits expression of NKp30 and NKG2D receptors: Consequences for the NK-mediated killing of dendritic cells. Proc. Natl. Acad. Sci. USA 2003, 100, 4120-4125. [CrossRef]

281. Kryczek, I.; Zou, L.; Rodriguez, P.; Zhu, G.; Wei, S.; Mottram, P.; Brumlik, M.; Cheng, P.; Curiel, T.; Myers, L.; et al. B7-H4 expression identifies a novel suppressive macrophage population in human ovarian carcinoma. J. Exp. Med. 2006, 203, 871-881. [CrossRef]

282. Matsuda, M.; Salazar, F.; Petersson, M.; Masucci, G.; Hansson, J.; Pisa, P.; Zhang, Q.J.; Masucci, M.G.; Kiessling, R. Interleukin 10 pretreatment protects target cells from tumor- and allo-specific cytotoxic T cells and downregulates HLA class I expression. J. Exp. Med. 1994, 180, 2371-2376. [CrossRef] [PubMed]

283. Flavell, R.A.; Sanjabi, S.; Wrzesinski, S.H.; Licona-Limón, P. The polarization of immune cells in the tumour environment by TGF 3 . Nat. Rev. Immunol. 2010, 10, 554-567. [CrossRef] [PubMed]

284. Schioppa, T.; Uranchimeg, B.; Saccani, A.; Biswas, S.K.; Doni, A.; Rapisarda, A.; Bernasconi, S.; Saccani, S.; Nebuloni, M.; Vago, L.; et al. Regulation of the chemokine receptor CXCR4 by hypoxia. J. Exp. Med. 2003, 198, 1391-1402. [CrossRef] [PubMed]

285. Suganami, T.; Ogawa, Y. Adipose tissue macrophages: Their role in adipose tissue remodeling. J. Leukoc. Biol. 2010, 88, 33-39. [CrossRef]

286. Gunasekaran, M.K.; Viranaicken, W.; Girard, A.-C.; Festy, F.; Cesari, M.; Roche, R.; Hoareau, L. Inflammation triggers high mobility group box 1 (HMGB1) secretion in adipose tissue, a potential link to obesity. Cytokine 2013, 64, 103-111. [CrossRef]

287. Lumeng, C.N.; Bodzin, J.L.; Saltiel, A.R. Obesity induces a phenotypic switch in adipose tissue macrophage polarization. J. Clin. Investig. 2007, 117, 175-184. [CrossRef]

288. Arendt, L.M.; Mccready, J.; Keller, P.J.; Baker, D.D.; Naber, S.P.; Seewaldt, V.; Kuperwasser, C. Obesity Promotes Breast Cancer by CCL2-Mediated Macrophage Recruitment and Angiogenesis. Cancer Res. 2013, 73, 6080-6093. [CrossRef]

289. Rogers, N.H.; Perfield, J.W.; Strissel, K.J.; Obin, M.S.; Greenberg, A.S. Reduced Energy Expenditure and Increased Inflammation Are Early Events in the Development of Ovariectomy-Induced Obesity. Endocrinology 2009, 150, 2161-2168. [CrossRef]

290. Colegio, O.R.; Chu, N.Q.; Szabo, A.L.; Chu, T.; Rhebergen, A.M.; Jairam, V.; Cyrus, N.; Brokowski, C.E.; Eisenbarth, S.C.; Phillips, G.M.; et al. Functional polarization of tumour-associated macrophages by tumour-derived lactic acid. Nature 2014, 513, 559-563. [CrossRef]

291. Spencer, M.; Yao-Borengasser, A.; Unal, R.; Rasouli, N.; Gurley, C.M.; Zhu, B.; Peterson, C.A.; Kern, P.A. Adipose tissue macrophages in insulin-resistant subjects are associated with collagen VI and fibrosis and demonstrate alternative activation. Am. J. Physiol. Metab. 2010, 299, E1016-E1027. [CrossRef]

292. Kim, Y.J.; Kim, E.-H.; Hahm, K.B. Oxidative stress in inflammation-based gastrointestinal tract diseases: Challenges and opportunities. J. Gastroenterol. Hepatol. 2012, 27, 1004-1010. [CrossRef] [PubMed]

293. Ziech, D.; Franco, R.; Pappa, A.; Panayiotidis, M.I. Reactive Oxygen Species (ROS)—-Induced genetic and epigenetic alterations in human carcinogenesis. Mutat. Res. Mol. Mech. Mutagen. 2011, 711, 167-173. [CrossRef] [PubMed]

294. Sica, A.; Larghi, P.; Mancino, A.; Rubino, L.; Porta, C.; Totaro, M.G.; Rimoldi, M.; Biswas, S.K.; Allavena, P.; Mantovani, A Macrophage polarization in tumour progression. Semin. Cancer Biol. 2008, 18, 349-355. [CrossRef]

295. Daoudi, M.; Derudas, B.; Gross, B.; Bories, G.; Wouters, K.; Brozek, J.; Caiazzo, R.; Raverdi, V.; Pigeyre, M.; Allavena, P.; et al. Human Adipose Tissue Macrophages Display Activation of cancer-related pathways. J. Biol. Chem. 2012, $287,21904-21913$. [CrossRef]

296. Leek, R.D.; Hunt, N.C.; Landers, R.J.; Lewis, C.E.; Royds, J.A.; Harris, A.L. Macrophage infiltration is associated with VEGF and EGFR expression in breast cancer. J. Pathol. 2000, 190, 430-436. [CrossRef] 
297. Bingle, L.; Lewis, C.E.; Corke, K.P.; Reed, M.; Brown, N.J. Macrophages promote angiogenesis in human breast tumour spheroids in vivo. Br. J. Cancer 2005, 94, 101-107. [CrossRef]

298. Vicioso, L.; Gonzalez, F.J.; Alvarez, M.; Ribelles, N.; Molina, M.; Marquez, A.; Perez, L.; Matilla, A.; Alba, E. Elevated serum levels of vascular endothelial growth factor are associated with tumor-associated macrophages in primary breast cancer. Am. J. Clin. Pathol. 2006, 125, 111-118. [CrossRef]

299. Lin, E.Y.; Li, J.F.; Bricard, G.; Wang, W.; Deng, Y.; Sellers, R.; Porcelli, S.A.; Pollard, J.W. Vascular endothelial growth factor restores delayed tumor progression in tumors depleted of macrophages. Mol. Oncol. 2007, 1, 288-302. [CrossRef]

300. Lin, E.Y.; Li, J.F.; Gnatovskiy, L.; Deng, Y.; Zhu, L.; Grzesik, D.A.; Qian, H.; Xue, X.; Pollard, J.W. Macrophages regulate the angiogenic switch in a mouse model of breast cancer. Cancer Res. 2006, 66, 11238-11246. [CrossRef]

301. Ojalvo, L.S.; King, W.; Cox, D.; Pollard, J.W. High-Density Gene Expression Analysis of Tumor-Associated Macrophages from Mouse Mammary Tumors. Am. J. Pathol. 2009, 174, 1048-1064. [CrossRef]

302. Leek, R.D.; Lewis, C.E.; Whitehouse, R.; Greenall, M.; Clarke, J.; Harris, A.L. Association of macrophage infiltration with angiogenesis and prognosis in invasive breast carcinoma. Cancer Res. 1996, 56, 4625-4629. [PubMed]

303. Schoppmann, S.F.; Birner, P.; Stöckl, J.; Kalt, R.; Ullrich, R.; Caucig, C.; Kriehuber, E.; Nagy, K.; Alitalo, K.; Kerjaschki, D. Tumor-associated macrophages express lymphatic endothelial growth factors and are related to peritumoral lymphangiogenesis. Am. J. Pathol. 2002, 161, 947-956. [CrossRef]

304. Balkwill, F.R. Cancer and the chemokine network. Nat. Cancer 2004, 4, 540-550. [CrossRef] [PubMed]

305. Baeriswyl, V.; Christofori, G. The angiogenic switch in carcinogenesis. Semin. Cancer Biol. 2009, 19, 329-337. [CrossRef]

306. Du, R.; Lu, K.V.; Petritsch, C.; Liu, P.; Ganss, R.; Passegué, E.; Song, H.; Vandenberg, S.; Johnson, R.S.; Werb, Z.; et al. HIF1alpha induces the recruitment of bone marrow-derived vascular modulatory cells to regulate tumor angiogenesis and invasion. Cancer Cell 2008, 13, 206-220. [CrossRef]

307. Zumsteg, A.; Baeriswyl, V.; Imaizumi, N.; Schwendener, R.; Rüegg, C.; Christofori, G. Myeloid Cells Contribute to Tumor Lymphangiogenesis. PLoS ONE 2009, 4, e7067. [CrossRef]

308. Rolny, C.; Mazzone, M.; Tugues, S.; Laoui, D.; Johansson, I.; Coulon, C.; Squadrito, M.L.; Segura, I.; Li, X.; Knevels, E.; et al. HRG inhibits tumor growth and metastasis by inducing macrophage polarization and vessel normalization through downregulation of PIGF. Cancer Cell 2011, 19, 31-44. [CrossRef] [PubMed]

309. Hos, D.; Schlereth, S.L.; Bock, F.; Heindl, L.M.; Cursiefen, C. Antilymphangiogenic therapy to promote transplant survival and to reduce cancer metastasis: What can we learn from the eye? Semin. Cell Dev. Biol. 2014, 38, 117-130. [CrossRef]

310. Padera, T.P.; Meijer, E.F.; Munn, L.L. The Lymphatic System in Disease Processes and Cancer Progression. Annu. Rev. Biomed. Eng. 2016, 18, 125-158. [CrossRef]

311. Lin, E.Y.; Pollard, J.W. Tumor-Associated Macrophages Press the Angiogenic Switch in Breast Cancer. Cancer Res. 2007, 67, 5064-5066. [CrossRef]

312. Hanahan, D.; Folkman, J. Patterns and Emerging Mechanisms of the Angiogenic Switch during Tumorigenesis. Cell 1996, 86, 353-364. [CrossRef]

313. De Bock, K.; Cauwenberghs, S.; Carmeliet, P. Vessel abnormalization: Another hallmark of cancer? Molecular mechanisms and therapeutic implications. Curr. Opin. Genet. Dev. 2011, 21, 73-79. [CrossRef] [PubMed]

314. Birbrair, A.; Zhang, T.; Wang, Z.M.; Messi, M.L.; Olson, J.D.; Mintz, A.; Delbono, O. Type-2 pericytes participate in normal and tumoral angiogenesis. Am. J. Physiol. Cell Physiol. 2014, 307, C25-C38. [CrossRef]

315. Hanahan, D.; Christofori, G.; Naik, P.; Arbeit, J. Transgenic mouse models of tumour angiogenesis: The angiogenic switch, its molecular controls, and prospects for preclinical therapeutic models. Eur. J. Cancer 1996, 32, 2386-2393. [CrossRef]

316. Stockmann, C.; Doedens, A.; Weidemann, A.; Zhang, N.; Takeda, N.; Greenberg, J.I.; Cheresh, D.A.; Johnson, R.S. Deletion of vascular endothelial growth factor in myeloid cells accelerates tumorigenesis. Nature 2008, 456, 814-818. [CrossRef]

317. Tang, X.; Mo, C.; Wang, Y.; Wei, D.; Xiao, H. Anti-tumour strategies aiming to target tumour-associated macrophages. Immunology 2013, 138, 93-104. [CrossRef]

318. Seandel, M.; Butler, J.; Lyden, D.; Rafii, S. A catalytic role for proangiogenic marrow-derived cells in tumor neovascularization. Cancer Cell 2008, 13, 181-183. [CrossRef]

319. Klimp, A.H.; Hollema, H.; Kempinga, C.; van der Zee, A.G.; de Vries, E.G.; Daemen, T. Expression of cyclooxygenase-2 and inducible nitric oxide synthase in human ovarian tumors and tumor-associated macrophages. Cancer Res. 2001, 61, 7305-7309.

320. Jonjić, N.; Valković, T.; Lucin, K.; Iternicka, Z.; Krstulja, M.; Mustać, E.; Dobi-Babić, R.; Sasso, F.; Melato, M. Comparison of microvessel density with tumor associated macrophages in invasive breast carcinoma. Anticancer Res. 1998, 18, 3767-3770.

321. Sunderkötter, C.; Goebeler, M.; Schulze-Osthoff, K.; Bhardwaj, R.; Sorg, C. Macrophage-derived angiogenesis factors. Pharmacol. Ther. 1991, 51, 195-216. [CrossRef]

322. Kaelin, W.G.; Ratcliffe, P.J. Oxygen Sensing by Metazoans: The Central Role of the HIF Hydroxylase Pathway. Mol. Cell 2008, 30, 393-402. [CrossRef] [PubMed]

323. Semenza, G.L. Hypoxia-Inducible Factors in Physiology and Medicine. Cell 2012, 148, 399-408. [CrossRef] [PubMed]

324. Bernhardt, W.M.; Wiesener, M.S.; Scigalla, P.; Chou, J.; Schmieder, R.E.; Günzler, V.; Eckardt, K.-U. Inhibition of Prolyl Hydroxylases Increases Erythropoietin Production in ESRD. J. Am. Soc. Nephrol. 2010, 21, 2151-2156. [CrossRef] [PubMed]

325. Vaupel, P.; Harrison, L. Tumor Hypoxia: Causative Factors, Compensatory Mechanisms, and Cellular Response. Oncologist 2004, 9, 4-9. [CrossRef] [PubMed] 
326. Barankay, T.; Baumgärtl, H.; Lübbers, D.W.; Seidl, E. 27 in small lymphatics. Pflugers Arch. 1976, 366, 53-59. [CrossRef]

327. Brown, J.M.; Giaccia, A.J. The unique physiology of solid tumors: Opportunities (and problems) for cancer therapy. Cancer Res. 1998, 58, 1408-1416.

328. Vaupel, P.; Kelleher, D.K.; Höckel, M. Oxygenation status of malignant tumors: Pathogenesis of hypoxia and significance for tumor therapy. Semin. Oncol. 2001, 28, 29-35. [CrossRef]

329. Chen, P.; Zuo, H.; Xiong, H.; Kolar, M.J.; Chu, Q.; Saghatelian, A.; Siegwart, D.J.; Wan, Y. Gpr132 sensing of lactate mediates tumor-macrophage interplay to promote breast cancer metastasis. Proc. Natl. Acad. Sci. USA 2017, 114, 580-585. [CrossRef]

330. Murdoch, C.; Giannoudis, A.; Lewis, C.E. Mechanisms regulating the recruitment of macrophages into hypoxic areas of tumors and other ischemic tissues. Blood 2004, 104, 2224-2234. [CrossRef]

331. Chae, Y.C.; Vaira, V.; Caino, M.C.; Tang, H.Y.; Seo, J.H.; Kossenkov, A.V.; Ottobrini, L.; Martelli, C.; Lucignani, G.; Bertolini, I.; et al. Mitochondrial Akt Regulation of Hypoxic Tumor Reprogramming. Cancer Cell 2016, 30, 257-272. [CrossRef]

332. Barsoum, I.B.; Hamilton, T.K.; Li, X.; Cotechini, T.; Miles, E.A.; Siemens, D.R.; Graham, C.H. Hypoxia induces escape from innate immunity in cancer cells via increased expression of ADAM10: Role of nitric oxide. Cancer Res. 2011, 71, 7433-7441. [CrossRef] [PubMed]

333. Zhang, C.C.; Sadek, H.A. Hypoxia and Metabolic Properties of Hematopoietic Stem Cells. Antioxid. Redox Signal. 2014, 20, 1891-1901. [CrossRef] [PubMed]

334. Giraudo, E.; Inoue, M.; Hanahan, D. An amino-bisphosphonate targets MMP-9-expressing macrophages and angiogenesis to impair cervical carcinogenesis. J. Clin. Investig. 2004, 114, 623-633. [CrossRef] [PubMed]

335. Kimbro, K.S.; Simons, J.W. Hypoxia-inducible factor-1 in human breast and prostate cancer. Endocr.-Relat. Cancer 2006, 13, 739-749. [CrossRef]

336. Murata, Y.; Ohteki, T.; Koyasu, S.; Hamuro, J. IFN-gamma and pro-inflammatory cytokine production by antigen-presenting cells is dictated by intracellular thiol redox status regulated by oxygen tension. Eur. J. Immunol. 2002, 32, 2866-2873. [CrossRef]

337. Giaccia, A.; Siim, B.G.; Johnson, R. HIF-1 as a target for drug development. Nat. Rev. Drug Discov. 2003, 2, 803-811. [CrossRef]

338. Leek, R.D.; Talks, K.L.; Pezzella, F.; Turley, H.; Campo, L.; Brown, N.S.; Bicknell, R.; Taylor, M.; Gatter, K.C.; Harris, A.L. Relation of hypoxia-inducible factor-2 alpha (HIF-2 alpha) expression in tumor-infiltrative macrophages to tumor angiogenesis and the oxidative thymidine phosphorylase pathway in Human breast cancer. Cancer Res. 2002, 62, 1326-1329.

339. Naugler, W.E.; Karin, M. The wolf in sheep's clothing: The role of interleukin-6 in immunity, inflammation and cancer. Trends Mol. Med. 2008, 14, 109-119. [CrossRef]

340. Folkman, J. Tumor angiogenesis: Therapeutic implications. N. Engl. J. Med. 1971, 285, 1182-1186. [CrossRef]

341. Cao, Y.; Arbiser, J.; D'Amato, R.J.; D'Amore, P.A.; Ingber, D.E.; Kerbel, R.; Klagsbrun, M.; Lim, S.; Moses, M.A.; Zetter, B.; et al. Forty-year journey of angiogenesis translational research. Sci. Transl. Med. 2011, 3, 114rv3. [CrossRef]

342. Ueda, S.; Saeki, T.; Osaki, A.; Yamane, T.; Kuji, I. Bevacizumab Induces Acute Hypoxia and Cancer Progression in Patients with Refractory Breast Cancer: Multimodal Functional Imaging and Multiplex Cytokine Analysis. Clin. Cancer Res. 2017, 23, 5769-5778. [CrossRef]

343. Hurwitz, H.; Fehrenbacher, L.; Novotny, W.; Cartwright, T.; Hainsworth, J.; Heim, W.; Berlin, J.; Baron, A.; Griffing, S.; Holmgren, E.; et al. Bevacizumab plus irinotecan, fluorouracil, and leucovorin for metastatic colorectal cancer. N. Engl. J. Med. 2014, 350, 2335-2342. [CrossRef]

344. Nowak, M.; Klink, M. The Role of Tumor-Associated Macrophages in the Progression and Chemoresistance of Ovarian Cancer. Cells. 2020, 9, 1299. [CrossRef] [PubMed]

345. Cannarile, M.A.; Weisser, M.; Jacob, W.; Jegg, A.M.; Ries, C.H.; Rüttinger, D. Colony-stimulating factor 1 receptor (CSF1R) inhibitors in cancer therapy. J. Immunother. Cancer. 2017, 5, 53. [CrossRef] [PubMed]

346. Ruiz Garcia, V.; López-Briz, E.; Carbonell Sanchis, R.; Gonzalvez Perales, J.L.; Bort-Marti, S. Megestrol acetate for treatment of anorexia-cachexia syndrome. Cochrane Database Syst. Rev. 2013, 2013, CD004310. [CrossRef] [PubMed]

347. Rosenberg, S.A.; Restifo, N.P. Adoptive cell transfer as personalized immunotherapy for human cancer. Science 2015, 348, 62-68. [CrossRef]

348. Lefebvre, M.L.; Krause, S.W.; Salcedo, M.; Nardin, A. Ex vivo-activated human macrophages kill chronic lymphocytic leukemia cells in the presence of rituximab: Mechanism of antibody-dependent cellular cytotoxicity and impact of human serum. $J$. Immunother. 2006, 29, 388-397. [CrossRef]

349. Tsao, L.C.; Crosby, E.J.; Trotter, T.N.; Agarwal, P.; Hwang, B.J.; Acharya, C.; Shuptrine, C.W.; Wang, T.; Wei, J.; Yang, X.; et al. CD47 blockade augmentation of trastuzumab antitumor efficacy dependent on antibody-dependent cellular phagocytosis. JCI Insight 2019, 4, e131882. [CrossRef]

350. Van Furth, R.; Cohn, Z.A.; Hirsch, J.G.; Humphrey, J.H.; Spector, W.G.; Langevoort, H.L. The mononuclear phagocyte system: A new classification of macrophages, monocytes, and their precursor cells. Bull. World Health Organ. 1972, 46, 845-852.

351. Gong, J.; Chehrazi-Raffle, A.; Reddi, S.; Salgia, R. Development of PD-1 and PD-L1 inhibitors as a form of cancer immunotherapy: A comprehensive review of registration trials and future considerations. J. Immunother. Cancer 2018, 6, 8. [CrossRef] 
352. Beck, L.A.; Thaçi, D.; Hamilton, J.D.; Graham, N.M.; Bieber, T.; Rocklin, R.; Ming, J.E.; Ren, H.; Kao, R.; Simpson, E.; et al. Dupilumab treatment in adults with moderate-to-severe atopic dermatitis. N. Engl. J. Med. 2014, 371, 130-139. [CrossRef] [PubMed]

353. Shiao, S.L.; Ruffell, B.; De Nardo, D.G.; Faddegon, B.A.; Park, C.C.; Coussens, L.M. TH2-Polarized CD4(+) T Cells and Macrophages Limit Efficacy of Radiotherapy. Cancer Immunol. Res. 2015, 3, 518-525. [CrossRef] [PubMed] 